\title{
العمل الخميري ودوره في الإصلاح المجتمعي من خلال السنة النبوية
}

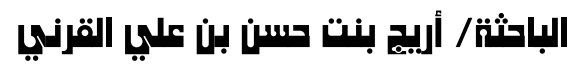

قسم الدراسات الإسلامية : السنة وعلومها (مساق فقه السنة)

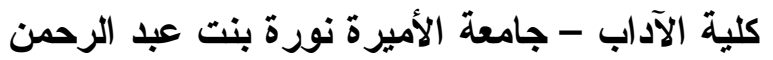

مقدمة الار اسةة:

إن الحمدلله تعالى نحمده ونستعينه ونستغفره ونعوذ به من شرور أنفسنا ومن ســيئات

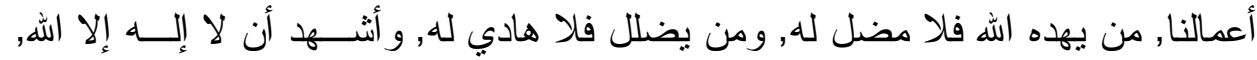

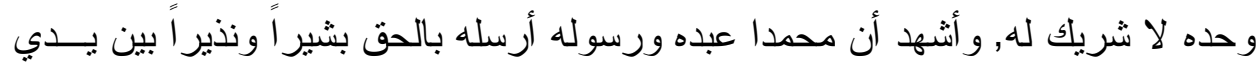

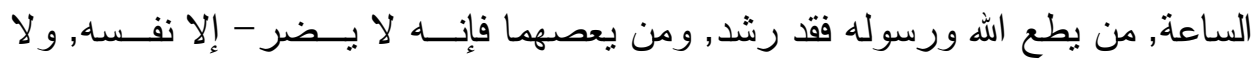
يضر - الله شيئا.

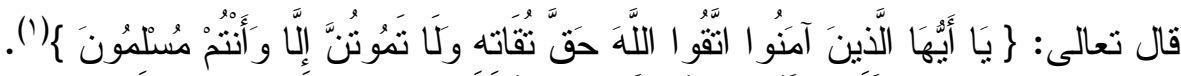

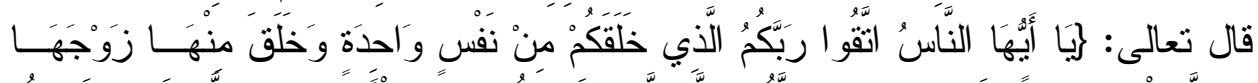

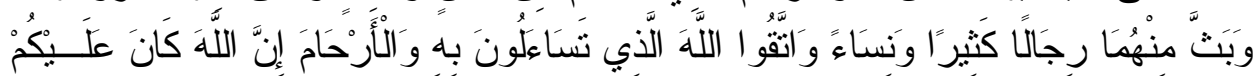

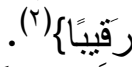

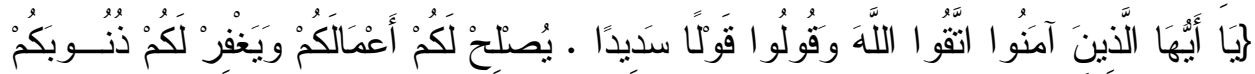

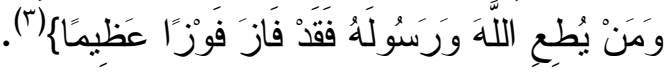
أهمبة البحث: الهن:

تمنل هذه الدراسة أهمية كبيرة في الواقع العلمي النظري ، وكذلك من الناحية التطبيقية

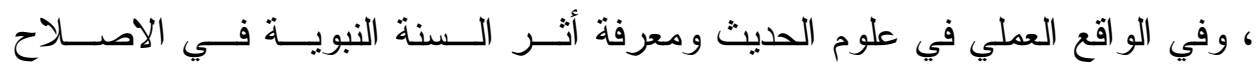

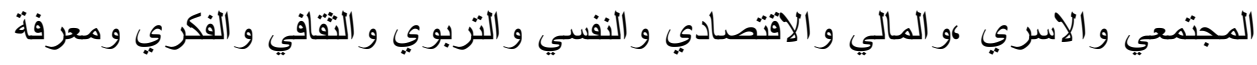

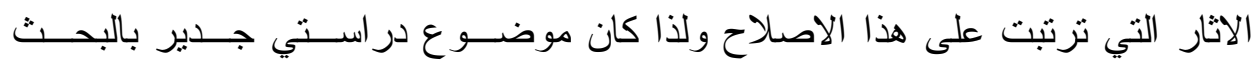
و الدر اسة.

$$
\begin{aligned}
& \text { (') سورة آل عمران، الآية: (r +1). } \\
& \text { (') سورة النساء، الآية: (1). }
\end{aligned}
$$

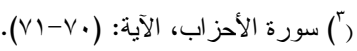


تكمن أهداف الدراسة و أسباب اختياره في ابراز النقاط التالية : 1. معرفة مفهوم العمل الخيري لغة و اصطلاحا.

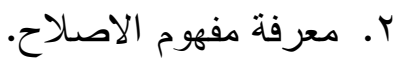
r. معرفة الأحاديث التي تدل على الاصنّ الصلاح المجتمعي. ء. معرفة الأحاديث التي تدل على الاصدلاح الأسري. ه. معرفة الأحاديث التي تدل على الاصدلاح المالي و الاقتصادي. 7. معرفة الأحاديث التي تدل على الاصلاح النفسي و التزبوي.

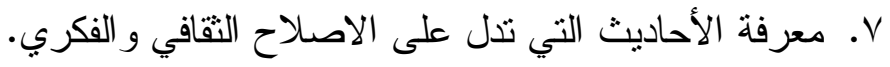

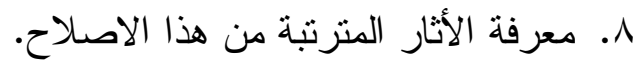

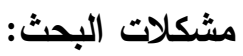

تكمن مشكلة الدر اسة في أن العمل الخيري والاصلاح من خلاص السنة النبوية المطهرة

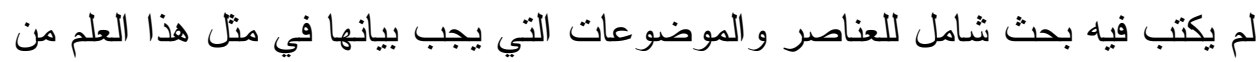

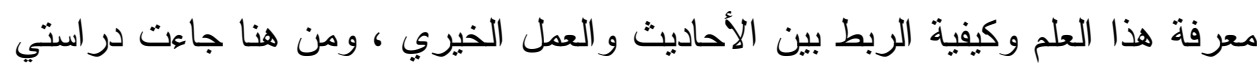

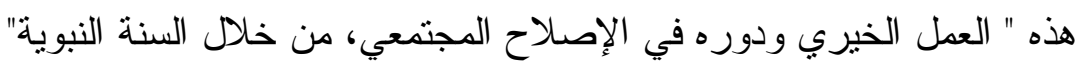

$$
\text { حدود البحث: البحل }
$$

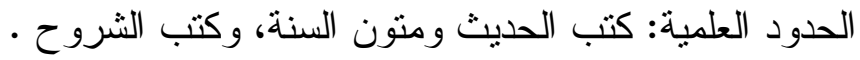

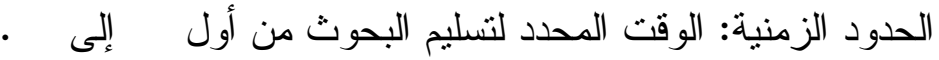

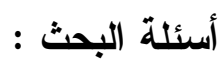

$$
\begin{aligned}
& \text { 1- ما هو مفهوم العمل الخيري ؟ } \\
& \text { r- ما هو الاصلاح لغة و اصطلاحا ؟ ها }
\end{aligned}
$$

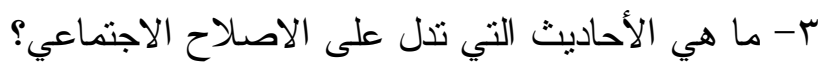

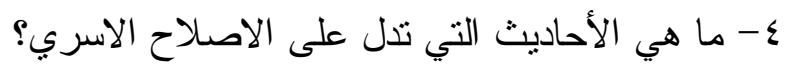

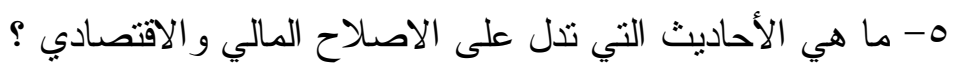

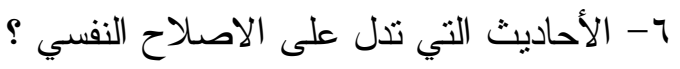

V- الأحاديث التي تدل على الاصدلاح الثقافي و الفكري ؟ لألفي

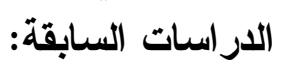

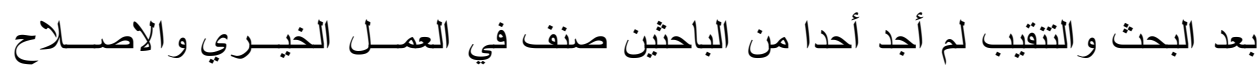

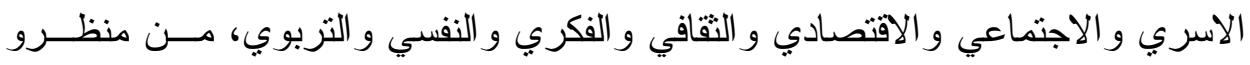


ومن خلال الأحاديث النبوية ، الا أنه وجدت بعض العناوين في هذا المجال من منظور

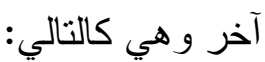
الار اسة الأولى: الإصلاح الاجتماعي في عهد الملك عبد العزيز ، لعبد الفتاح حسن أبــو

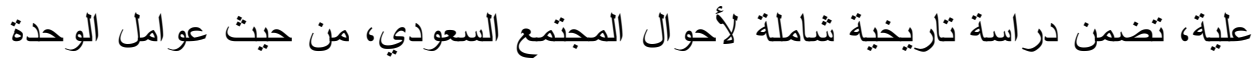
و التفكل، ومشكلات البدو و الحضر في مجتمعات الحجاز ونجد و الإحساء.

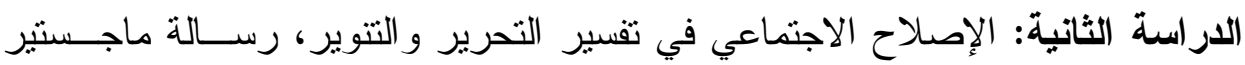

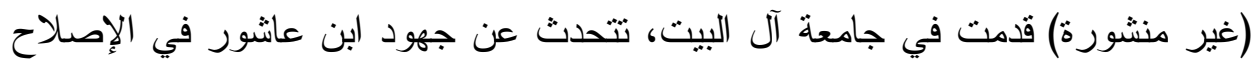
الاجتماعي، من خلال تفسيره التحرير و التتوير وخاصة في المجنمع التونسي .

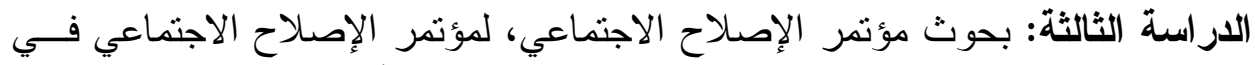

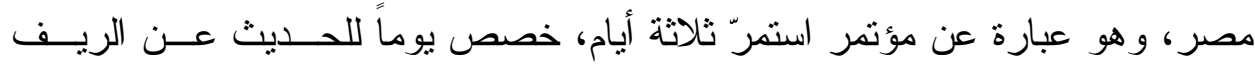

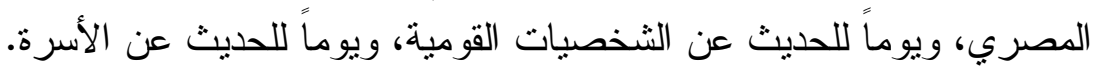

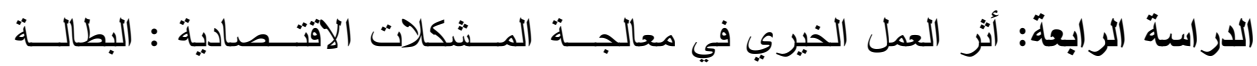

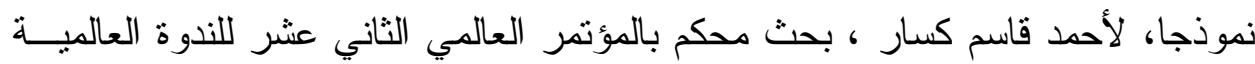

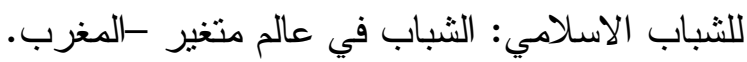

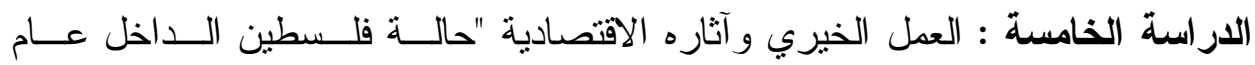

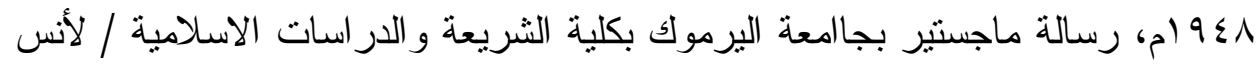

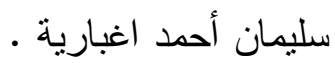
منهج الاراسة :

o استخدمت في بحثي هذا المنهج الاستقر ائي, ثم التحليلي، و التطبيقي حيث أقــوم باستقر اء ما أستطيع أن أقف عليه من المصنفات المتعلقة بعلوم الحديث و السنة ولئة المتعلقة بالأزمة من حينها.

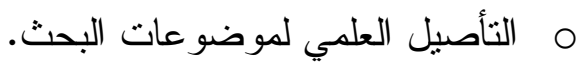

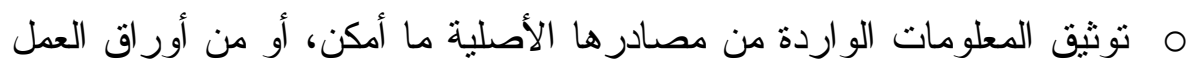

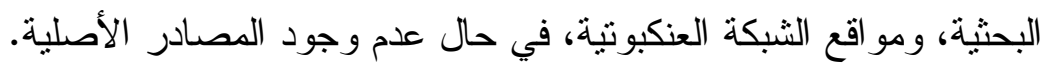
O ت تناول موضو عات البحث بحكمة ورويَّة. o التعريف ببعض الكلمات و المصطلحات التي تحتاج إلى إيضاح.

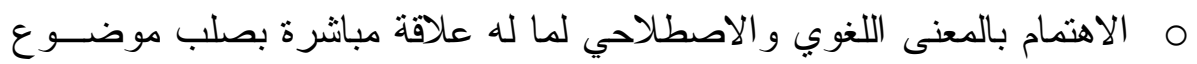
البحث. o عزو الآيات القر آنية, باسم السورة ورقم الآية. 
م إذا كان الحديث مذكور اً في الصحيحين, أو أحدهما, فإنه يكتفي بهما, و أمسـا إذا

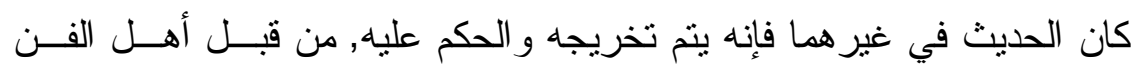
المختصين. م الترجمة للأعلام الوارد ذكرهم في البحث ما لم يتكرر ذكــرهم, فـــإن تكــرر

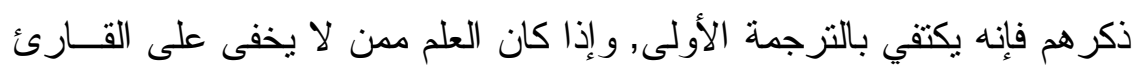

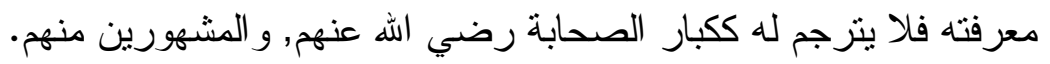

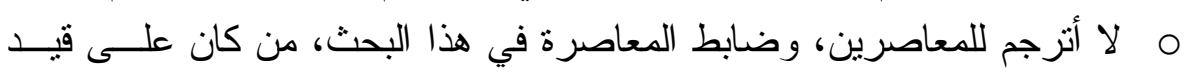
الحياة.

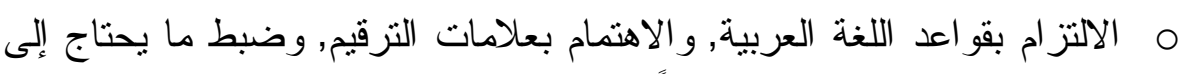
ضبط ما استطعت إلى ذلك سبيلاً. O وضع الخاتمة وما تحتويه من نتائج ونوصيات. O موضعت فهارس علمية على النحو التالي :

$$
\begin{array}{r}
0 \\
0 \\
0 \\
\text { - } 0
\end{array}
$$

خطة البحث

لقد قسمت البحث إلى مقدمة، وتمهيد، و اربعة مباحث، وخاتمة 
ثانيًا: التمهيد: مفهوم العمل الخيري ، والإصلاح المجتمعي .

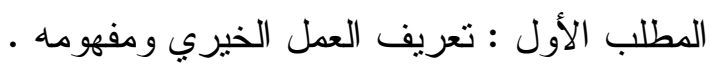

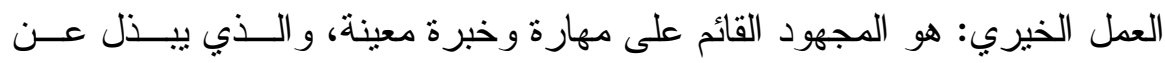

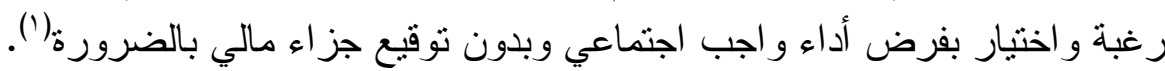

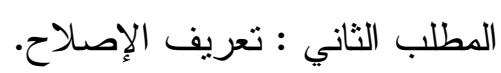
ا - تعريف الإصلاح لغة و اصطلاحاً:

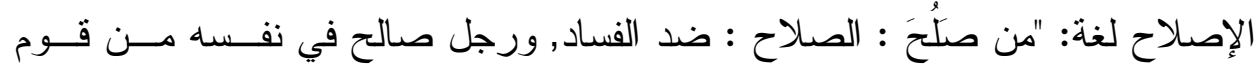

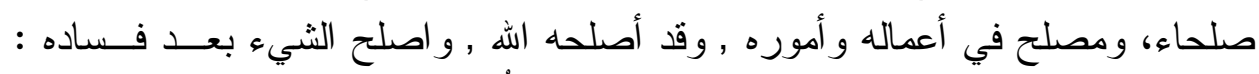

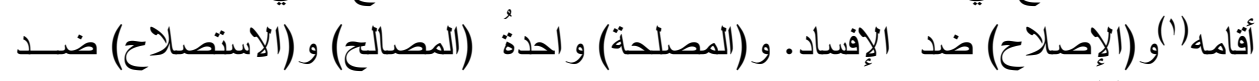

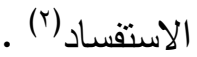

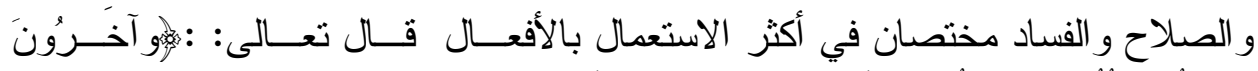

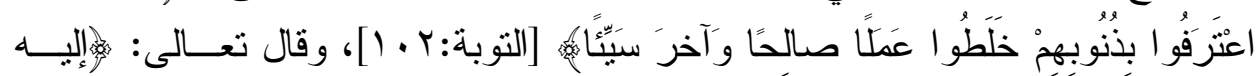

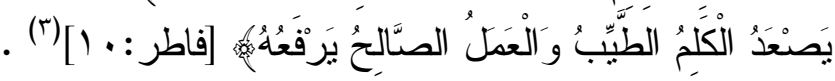

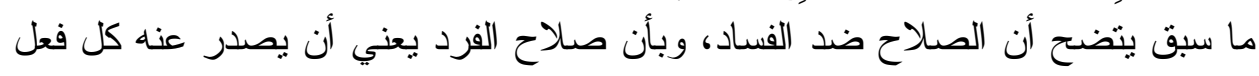

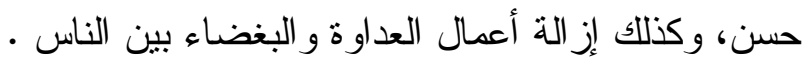

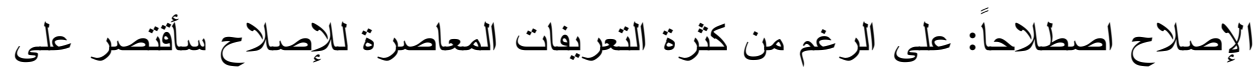

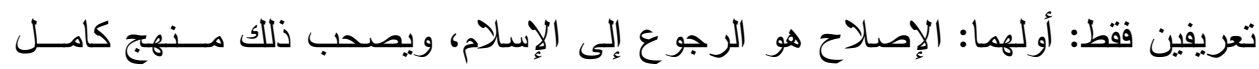

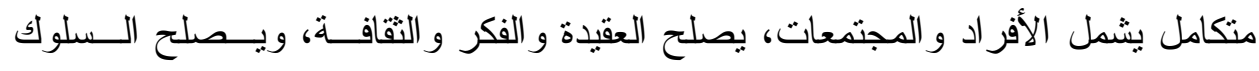

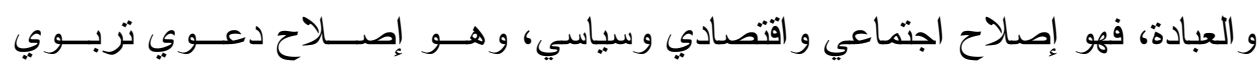
تتظيمي شامل منكامل (0). ويعرف الإصلاح: أيضا انه " هو تصويب ما أعوج في ممارسة أمور الــدين والــدنيا

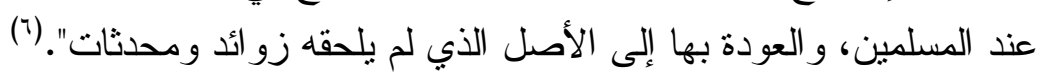


المبحث الأول: العمل الخيري وأثره في الإصلاح الأســــي والإجتمــاعي مـن خــله الأحاديث النبوية.

\section{المطلب الأول: الأحاديث الواردة في الإصلاح الأسري والاجتماعي.}

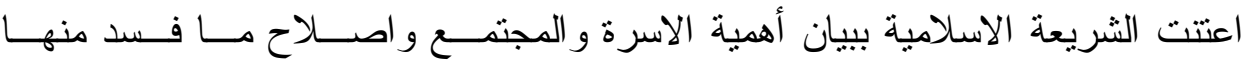

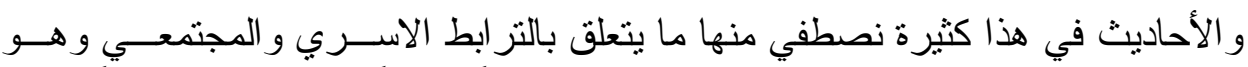

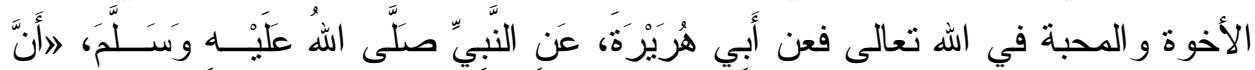

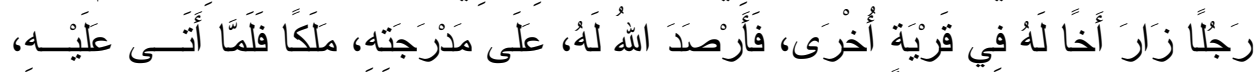

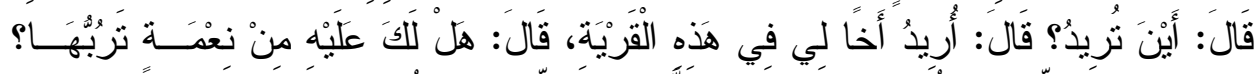

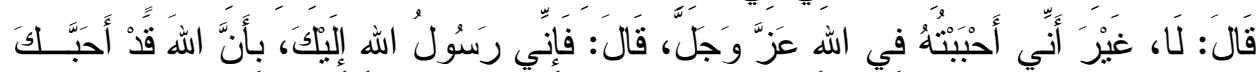

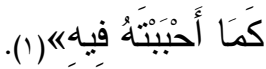

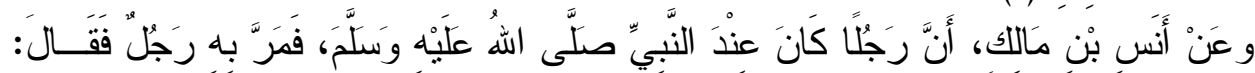

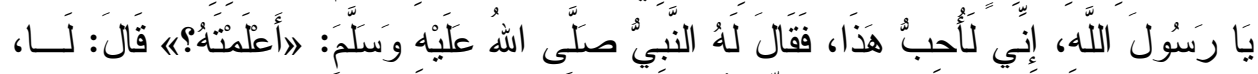

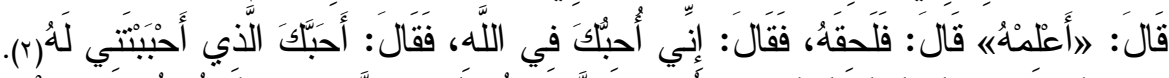

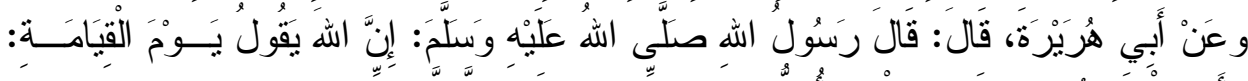

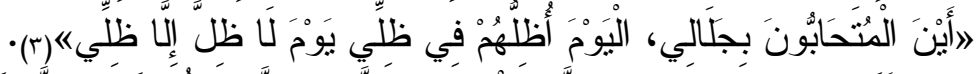

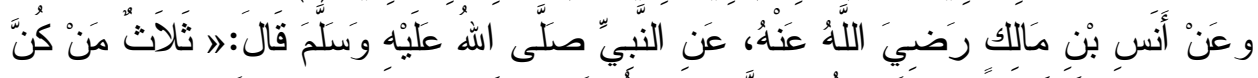

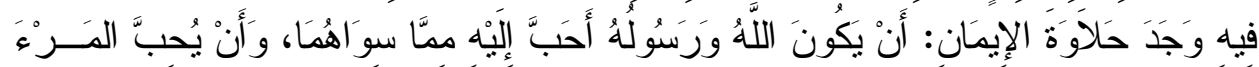

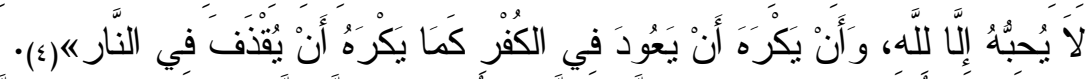

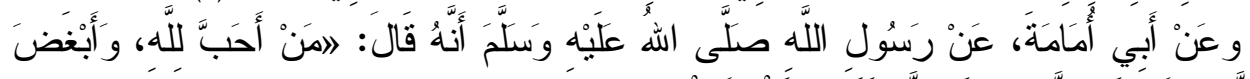

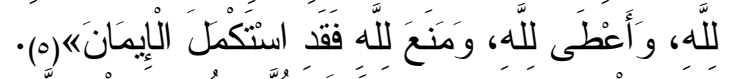

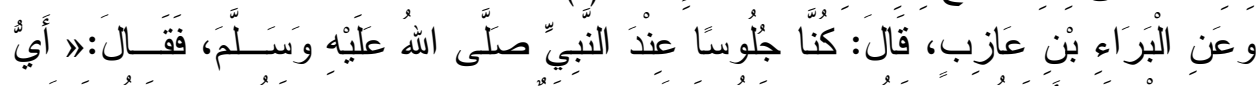

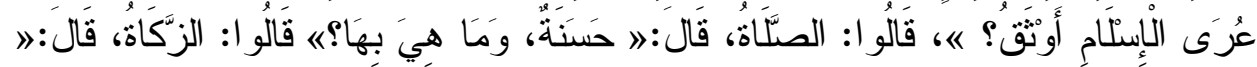

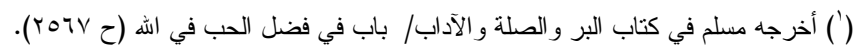

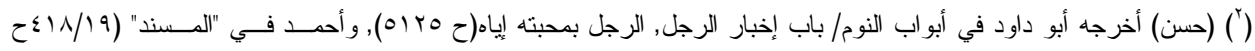

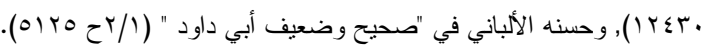

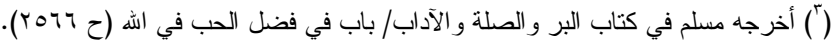

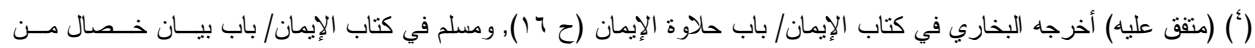
اتصف بهن وجد حلاوة الإيمان (ح ع آح).

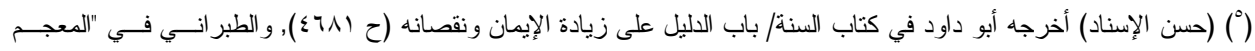

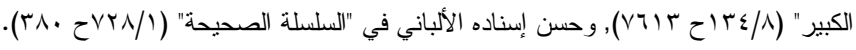




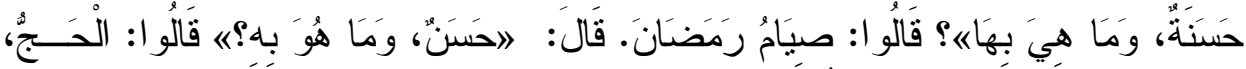

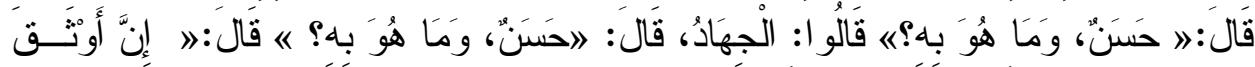

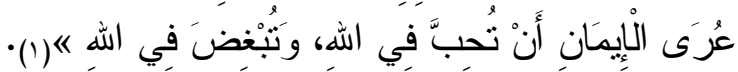

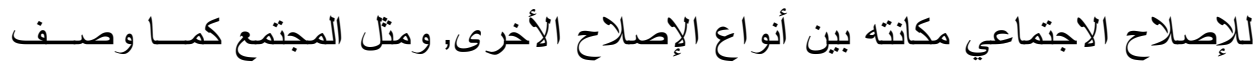

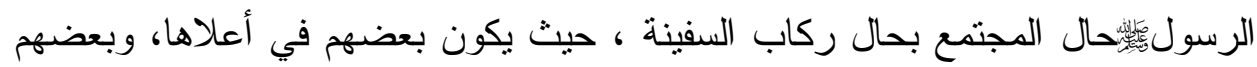

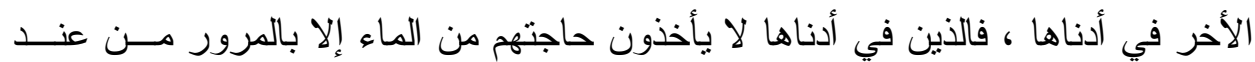

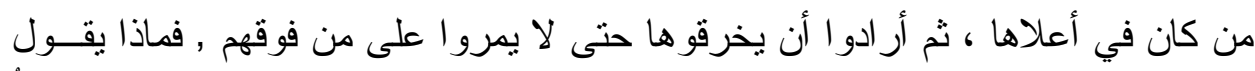

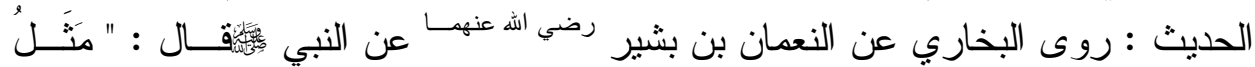

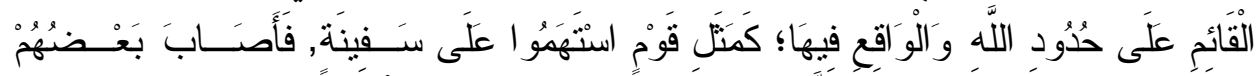

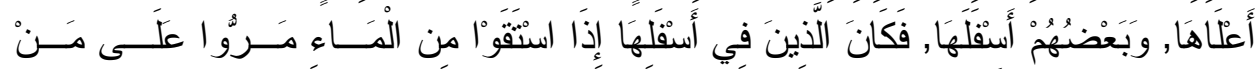

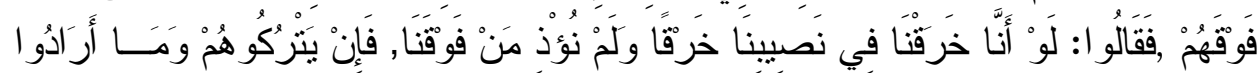

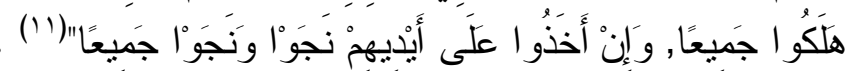

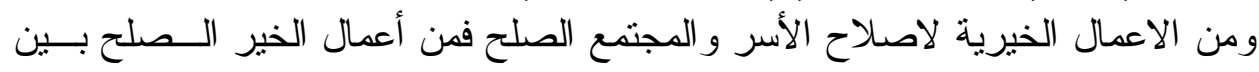
الناس قال ابن القيم: - الاعمان:

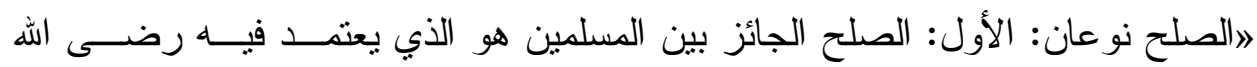

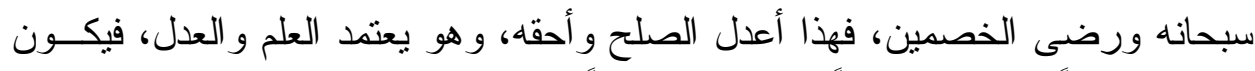

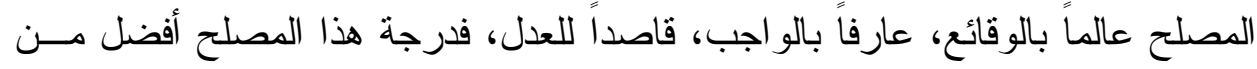

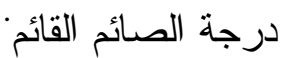

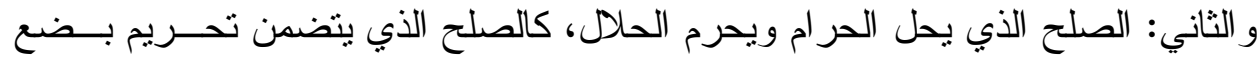

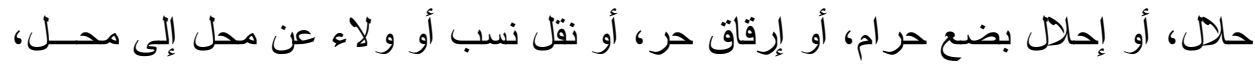

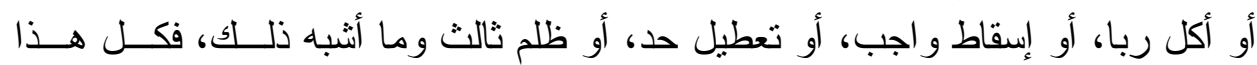

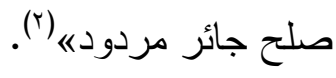
ويدل على تحريم هذا الصلح جملة من الأدلة، منها:

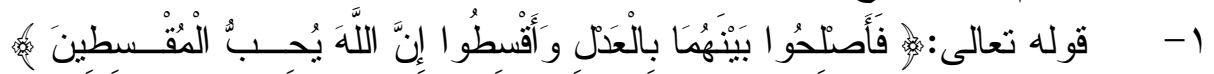

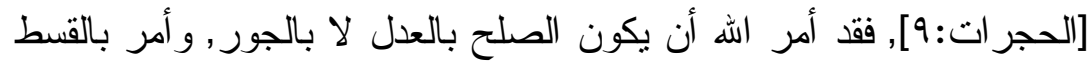
في ذلك، وأخبر عن محبته للمقسطين العادلين في أحكامهم.

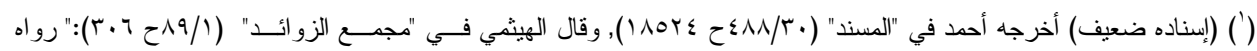

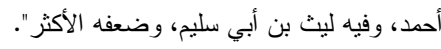

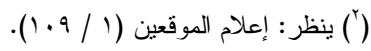




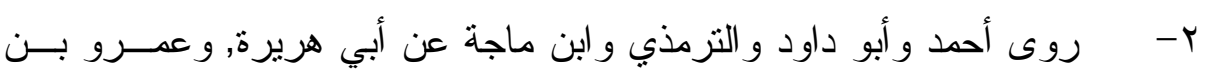

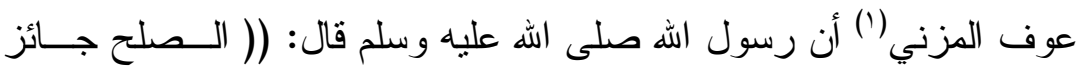

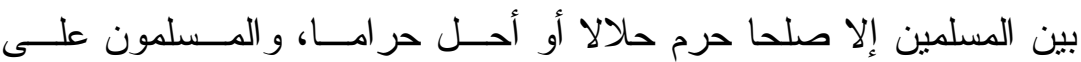

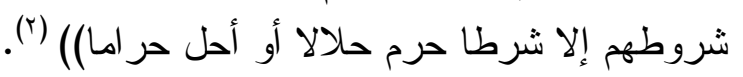

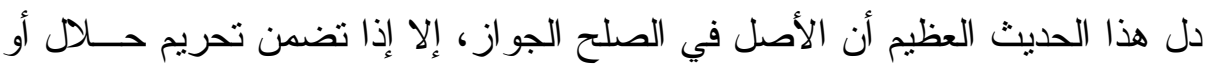

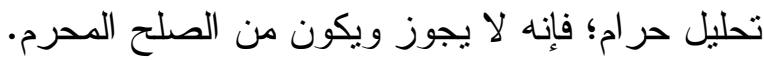

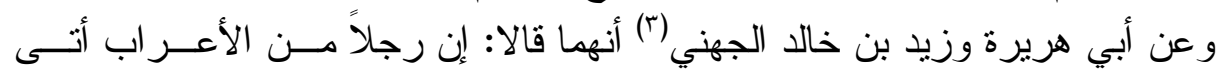

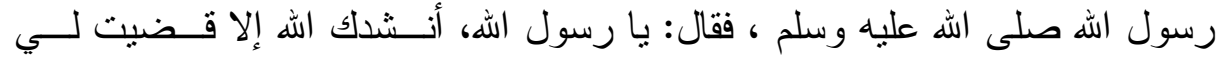
بكتاب الله، فقال الخصم الآخر - وهو أفقه منه-: نعم، فاقض بينتا بكتاب الله و ائــنـن

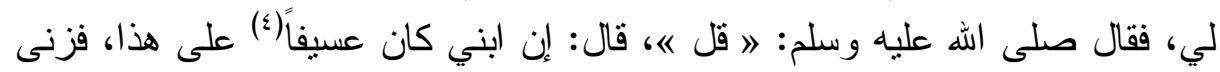

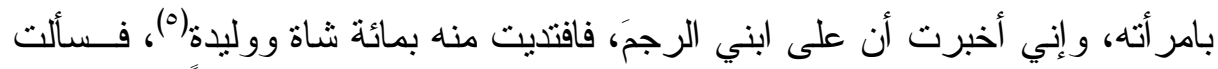

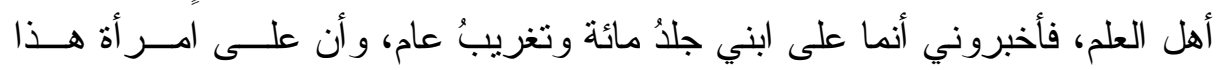

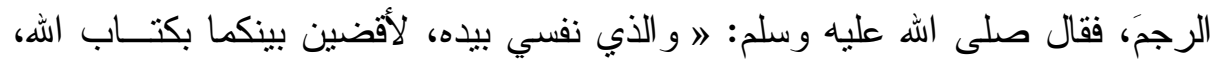

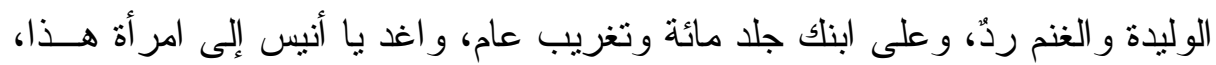

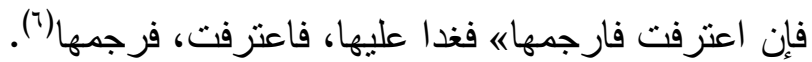

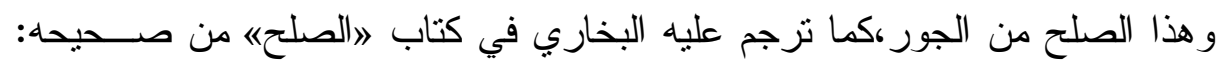

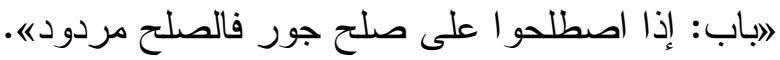

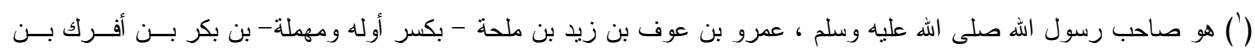

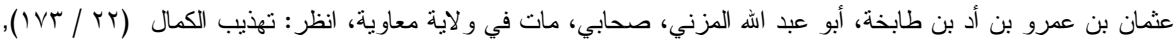

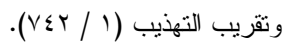

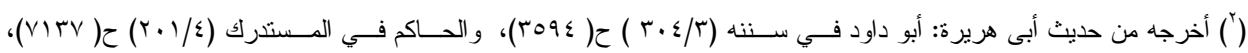

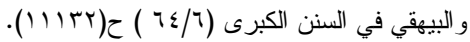

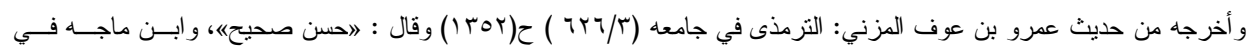

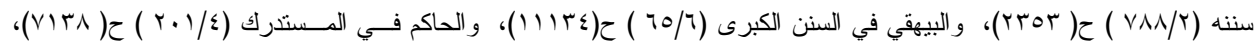

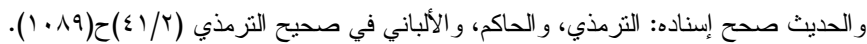

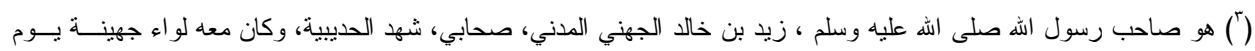

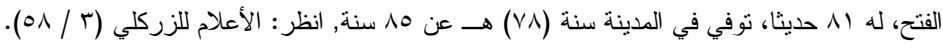

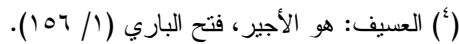

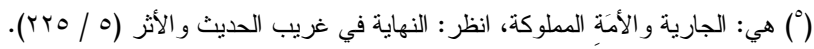

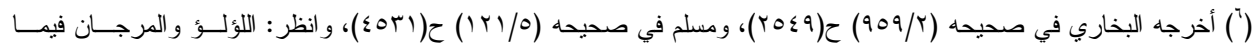

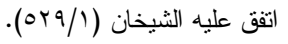


ووجه الشاهد من هذا الحديث: أنه لما اصطلح هذان الرجلان على إبطال الحدِّ فـي

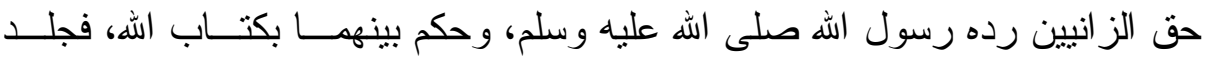

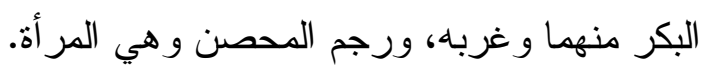
فيجب على من سعى بالصلح بين المسلمين أن يحرص على أن أن يكون صلحه الحه بالعدل

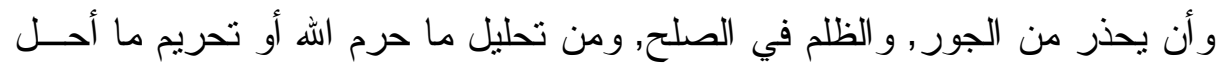

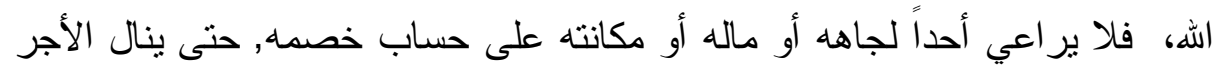

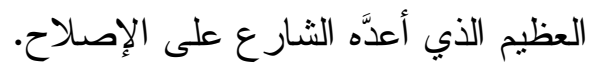

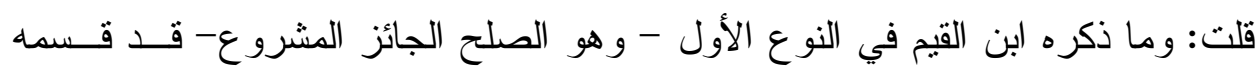

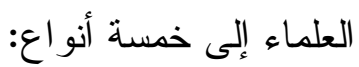
النوع الأول: الصلح بين المسلمين و أهل الحرب, كما في صلح الحديبية بين النبي صلى فلى الله عليه وسلم و أصحابه وبين كفار قريش.

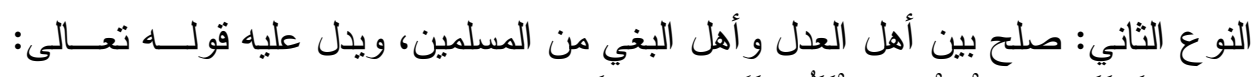

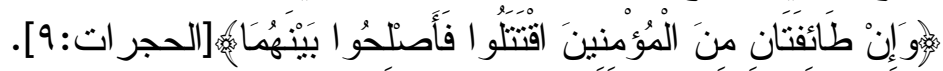

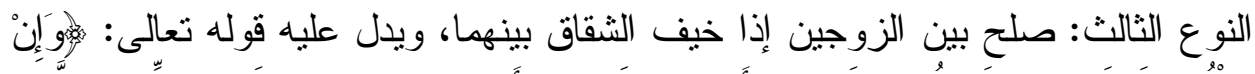

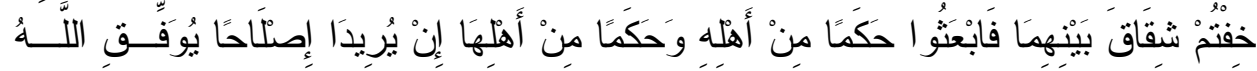

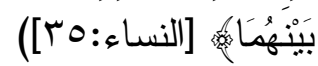

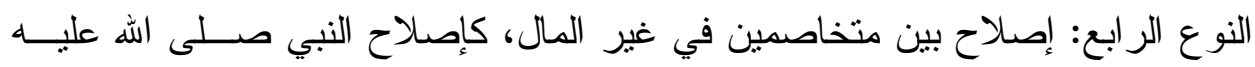
وسلم بين أناس من بني عمرو بن عوف في خصومة كانت بينهم.

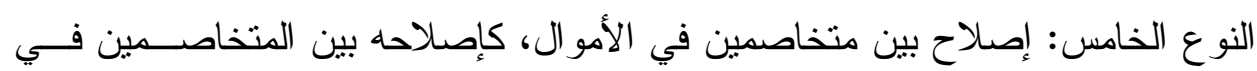

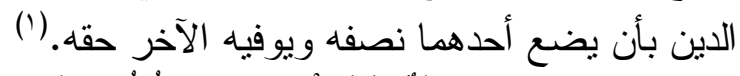

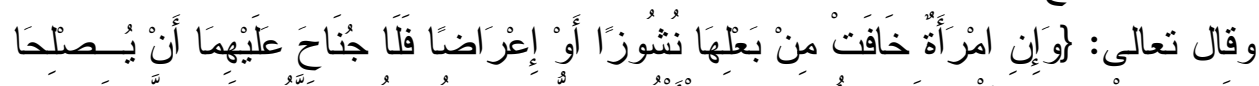

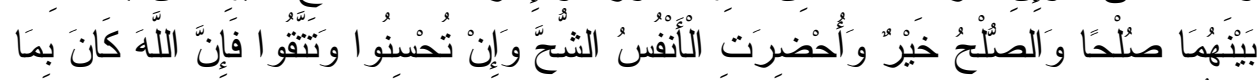

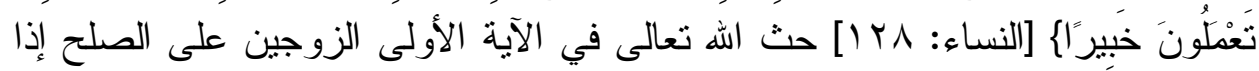

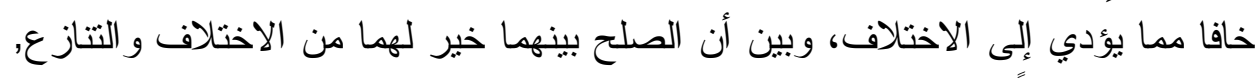
قال الطبري مبيناً معنى الآية: 


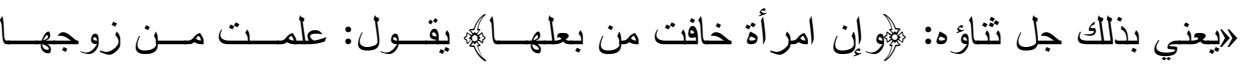

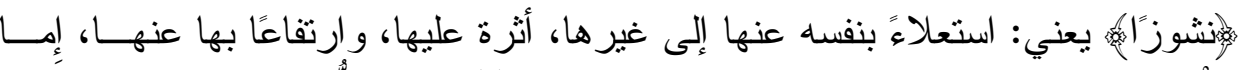

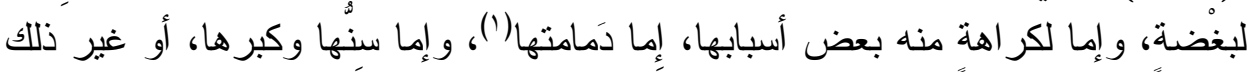

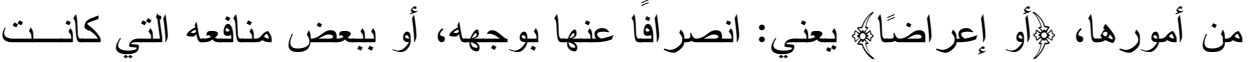

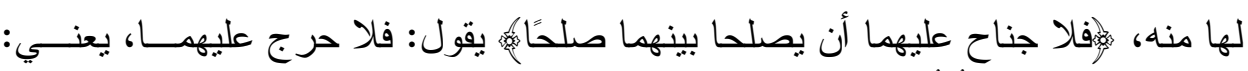

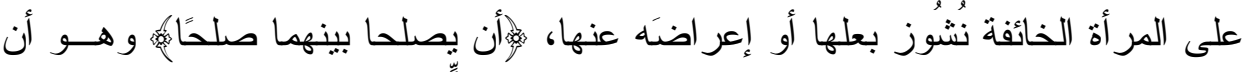

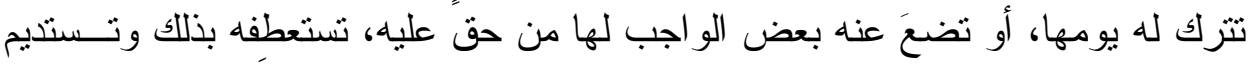

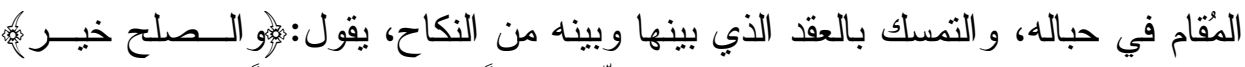

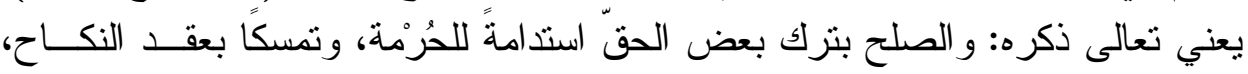

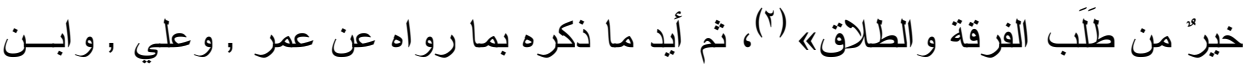

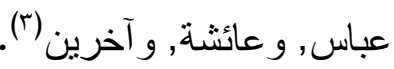

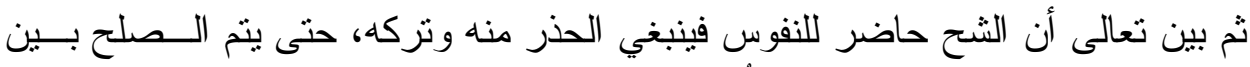

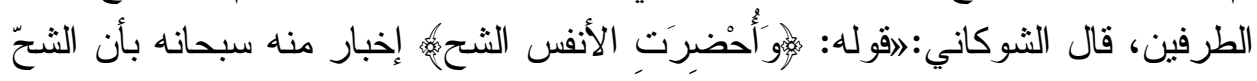

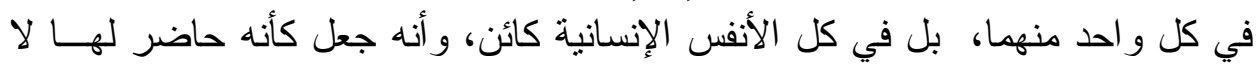

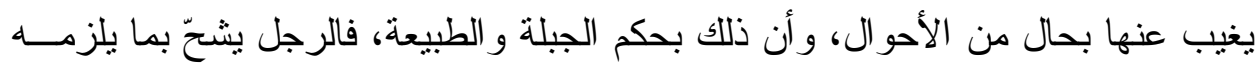

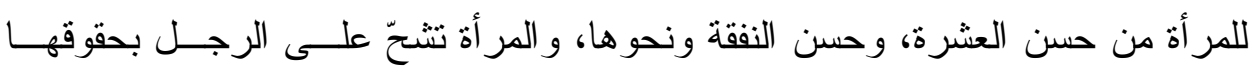

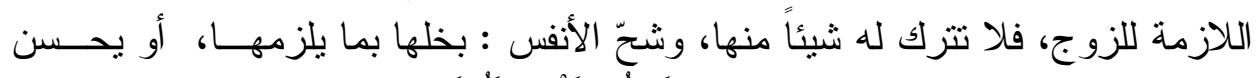

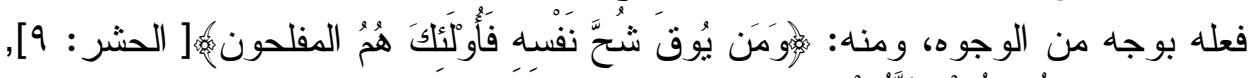

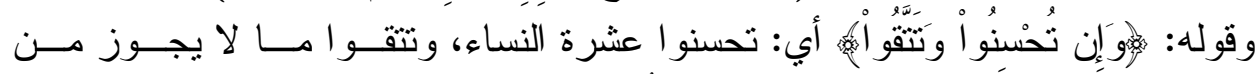

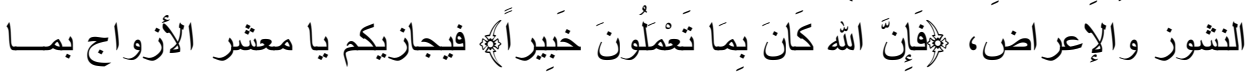
تشتحقونه « (๕)

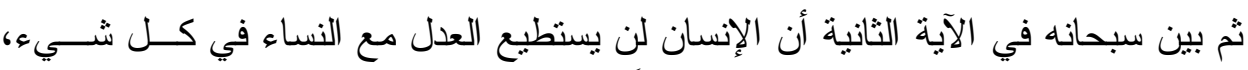
ولكن فيما يقدر عليه، قال ابن كثير موضحاً معنيّ الآية:

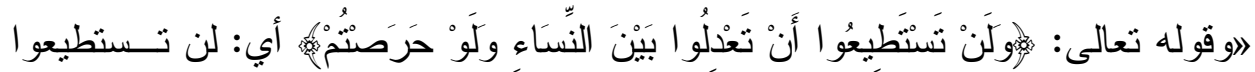

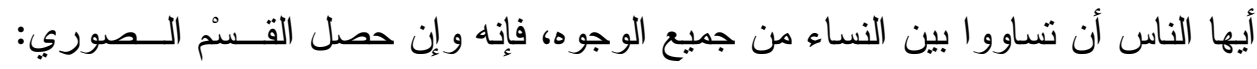


ليلة وليلة، فلا بد من التفاوت في المحبة والثهوة و الجماع، كما قاله ابن عباس ..《، ثم قال:

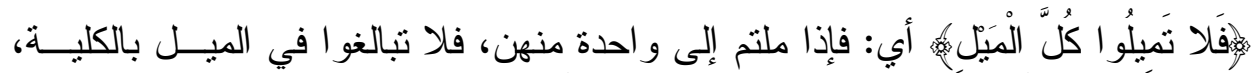

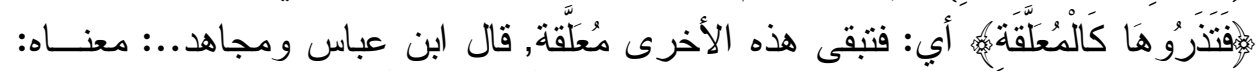

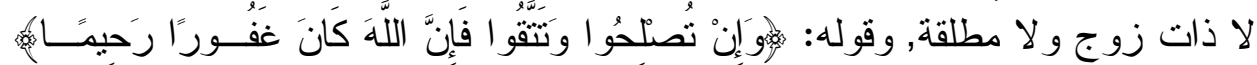

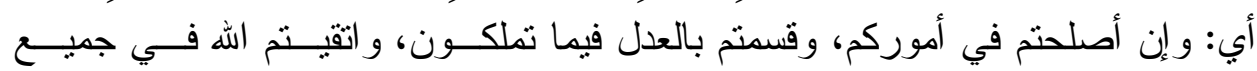

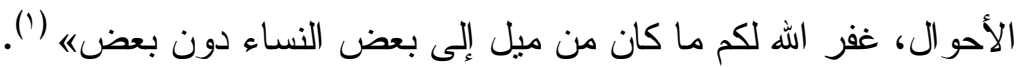

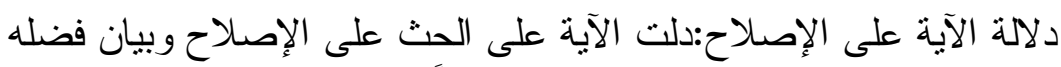

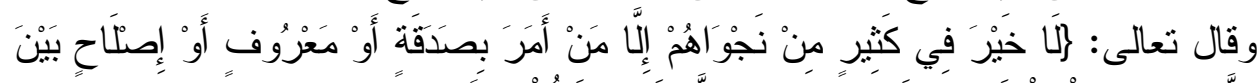

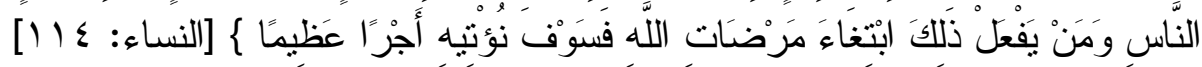

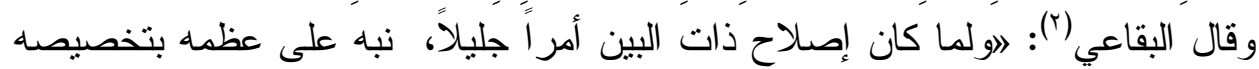

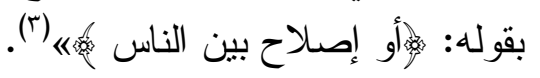

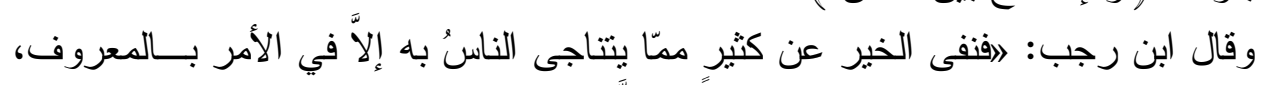

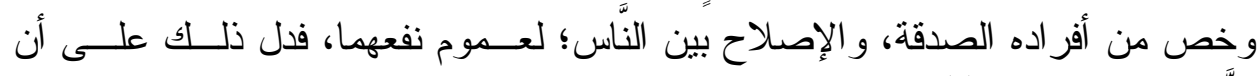

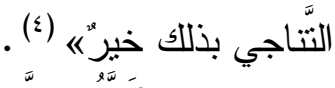

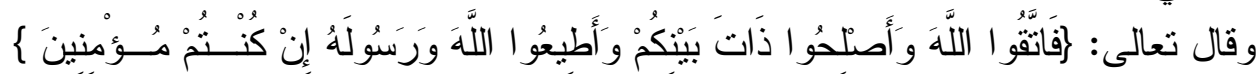

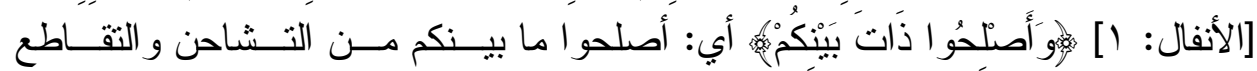
و التدابر ، بالتو ادد و التحاب و التو اصل، فبذلك تجتمع كلمتكم، ويزول ما يحصل - بسبب

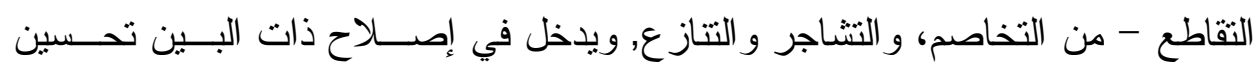

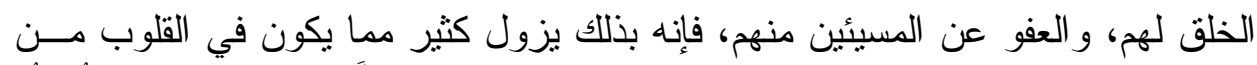

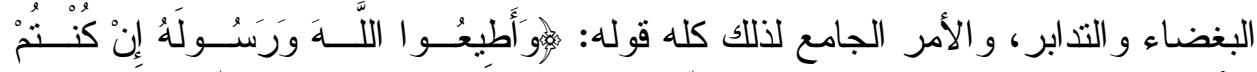

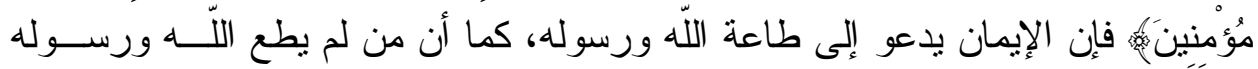

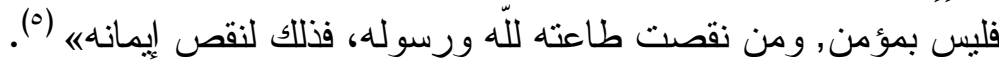

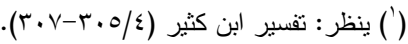

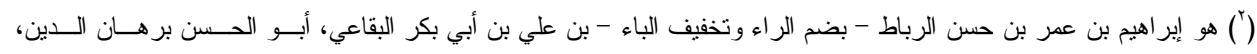

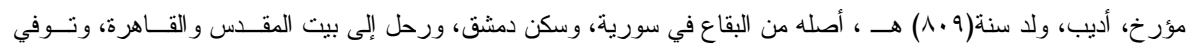

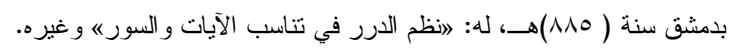

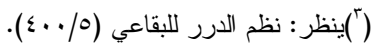

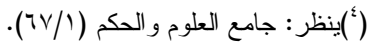

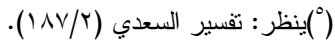




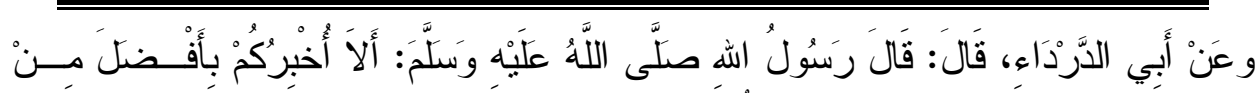

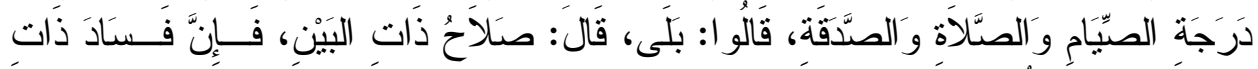

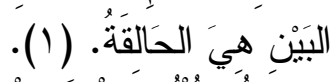

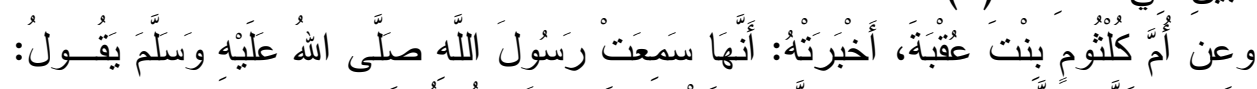

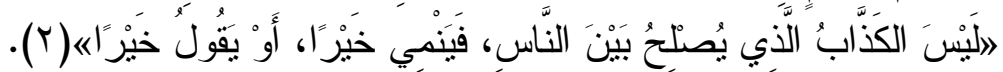
وعن أبي الدرداء - رضي الله عنه- قال: قال رسول الله صلى الله عليه وسلم:

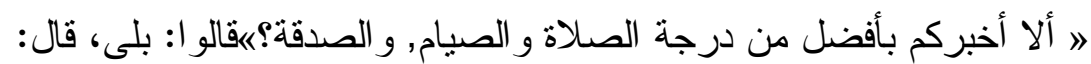

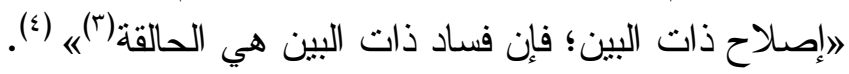

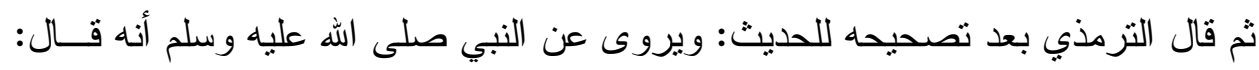

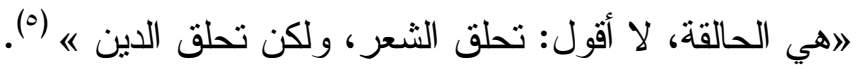

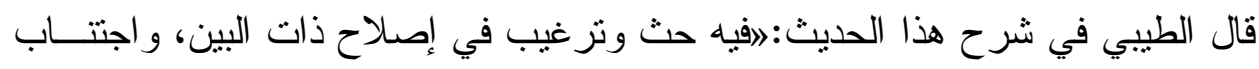

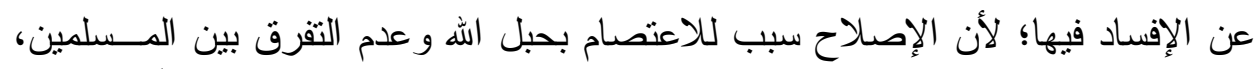

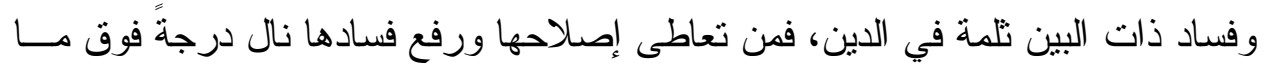

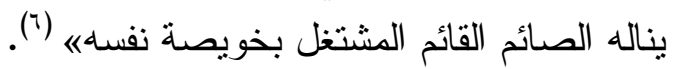

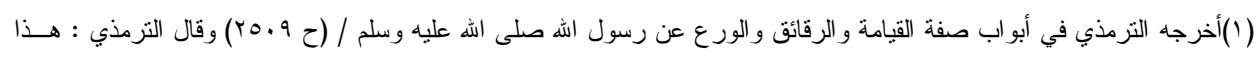

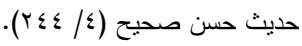

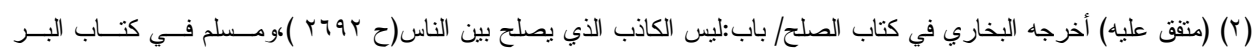

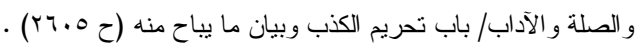

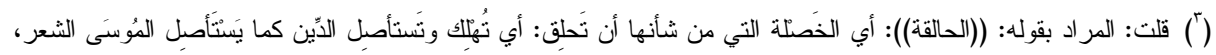

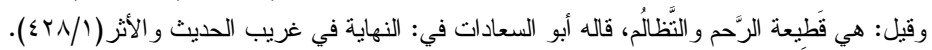

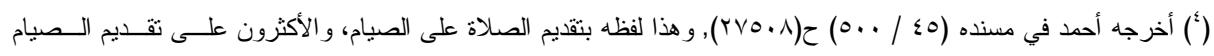

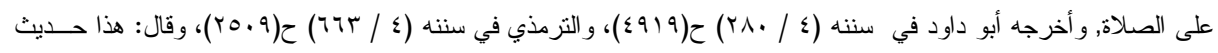

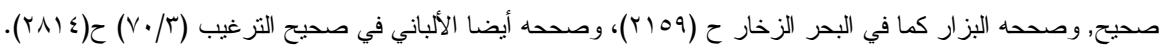

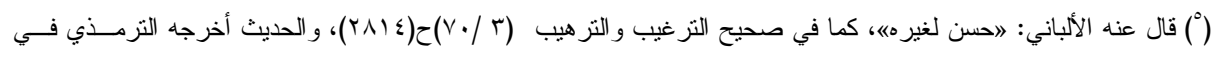

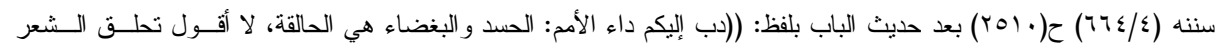

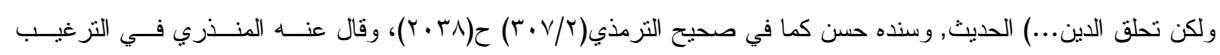

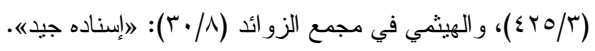

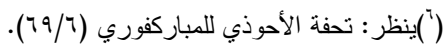


و عن أبي هريرة رضي الله عنه، عن رسول الله صلى الله عليه وسلم قال:اها عمل ابن

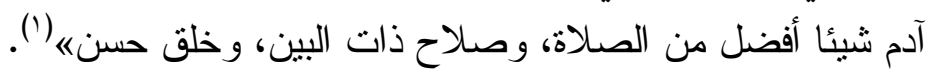

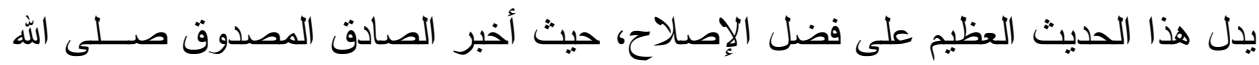

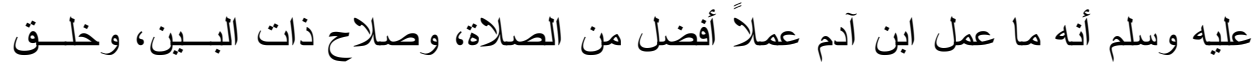

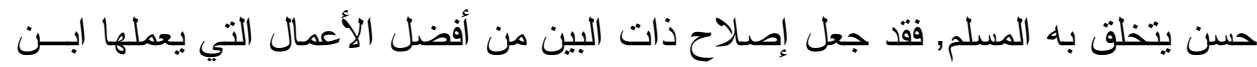
آدم, و هذا لاشك يدل على فضله و أهميته.

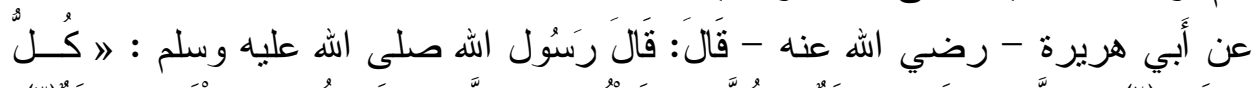

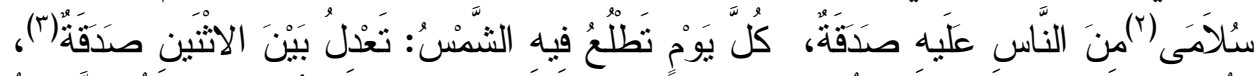

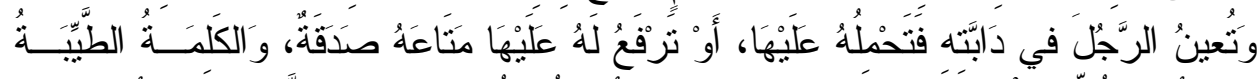

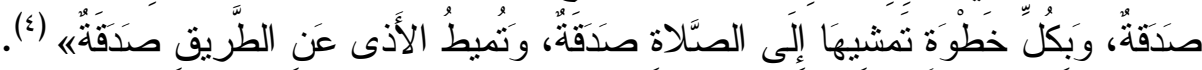

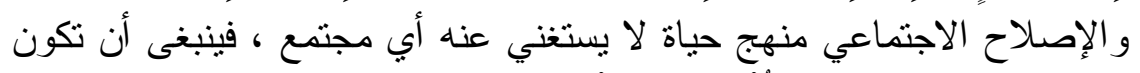

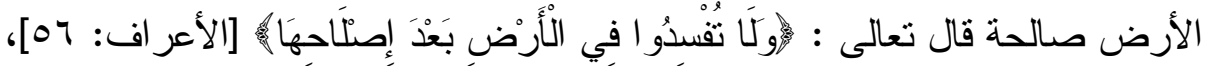

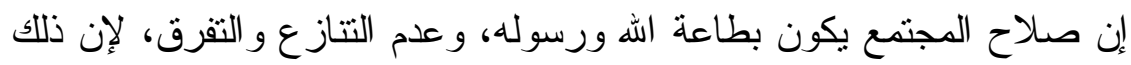

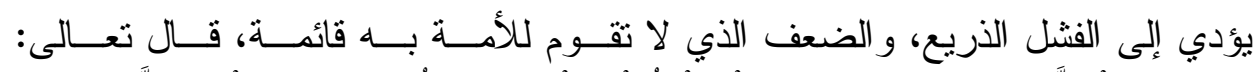

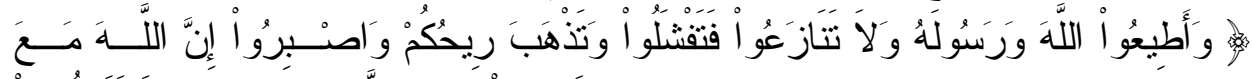

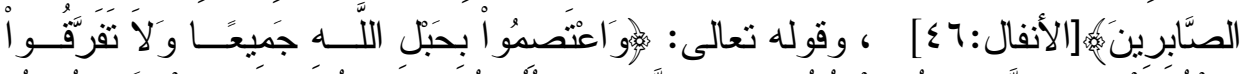

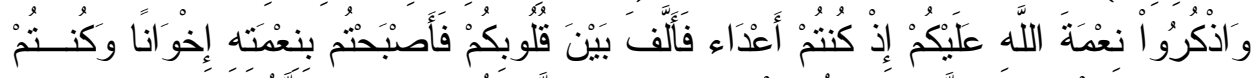

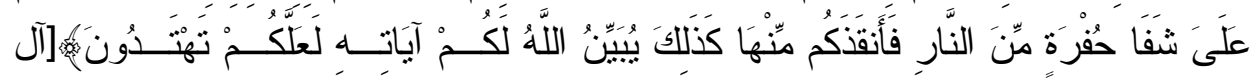

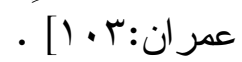

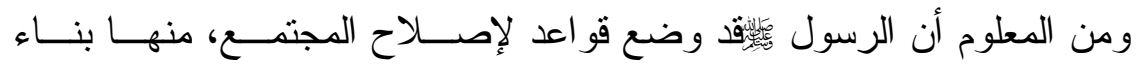

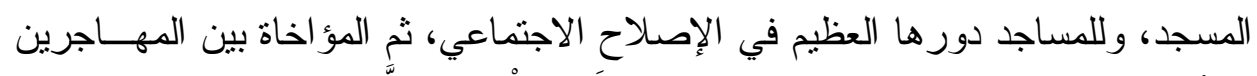

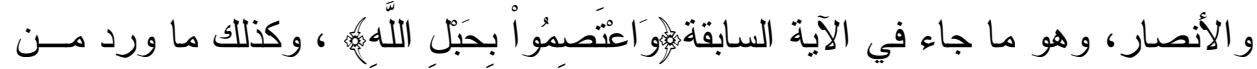

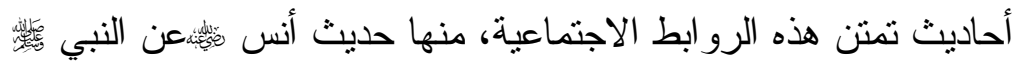

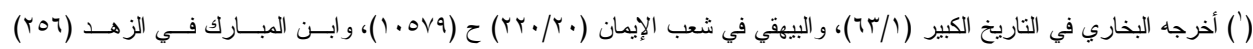

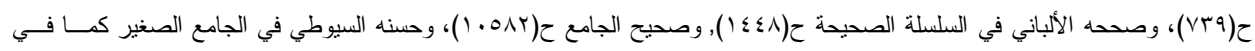
فيض القدير : (V/OV/O ع).

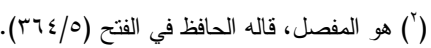

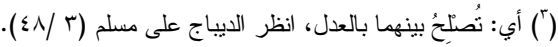

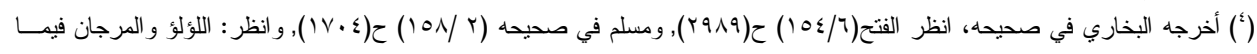
انفق عليه الشيخان (I/Tr/Y). 


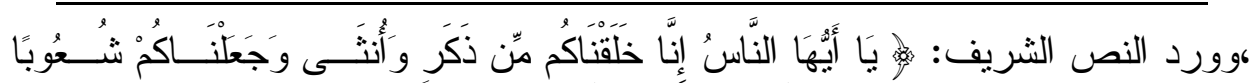

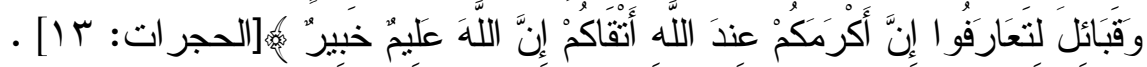

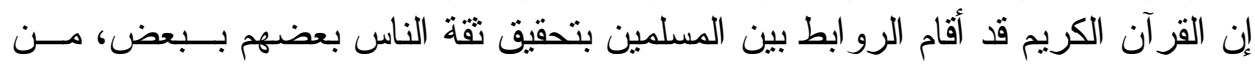

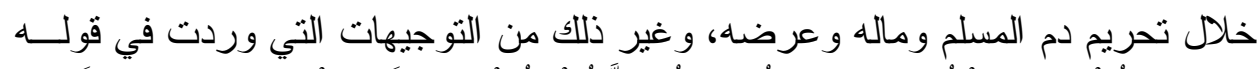

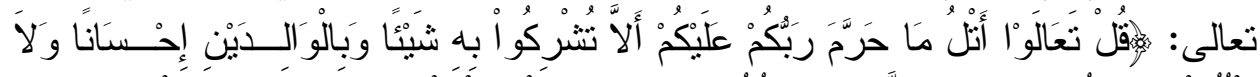

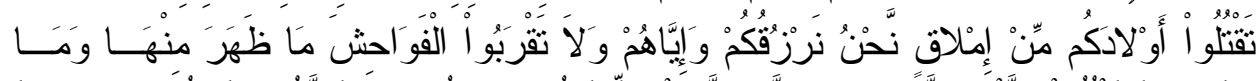

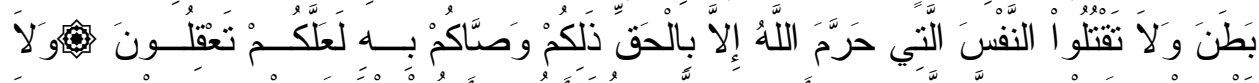

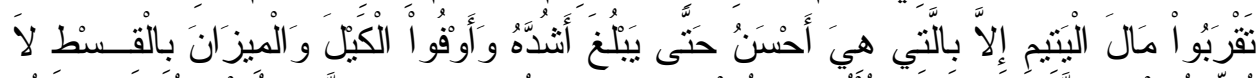

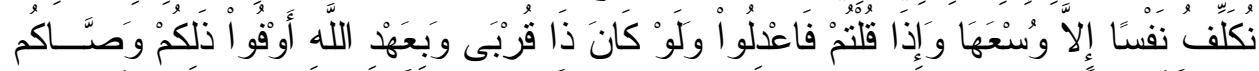

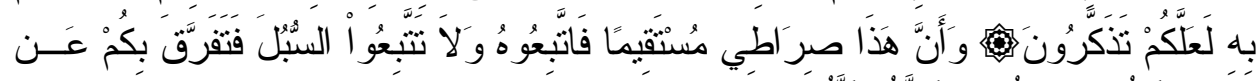

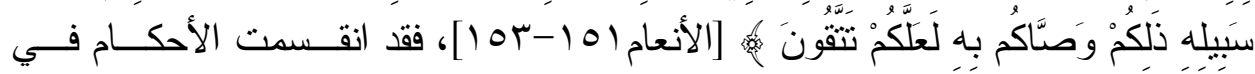

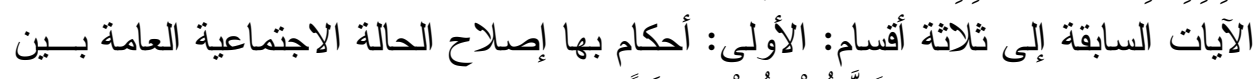

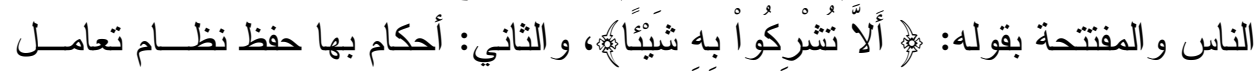

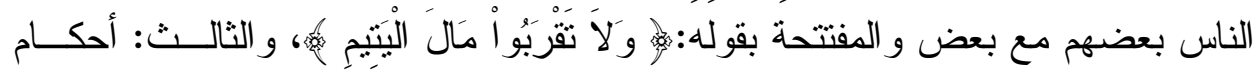

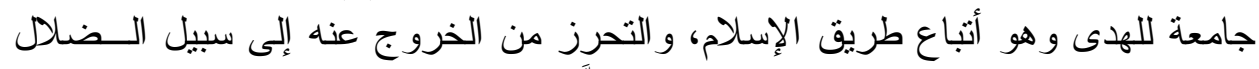

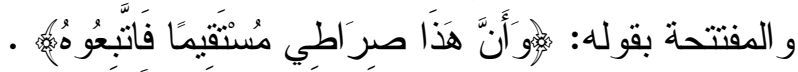

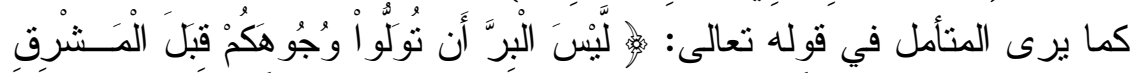

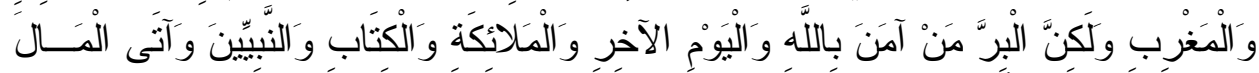

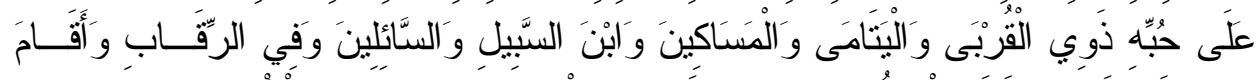

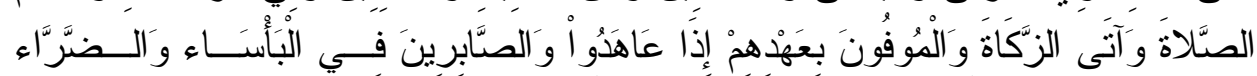

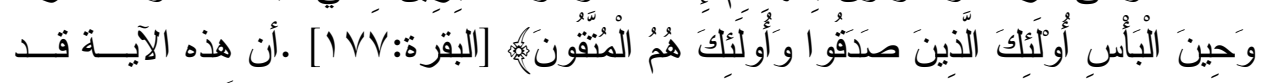

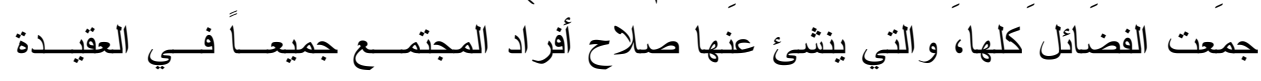
وصالحات الأعمال.

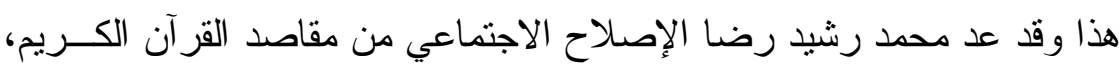

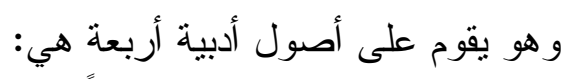

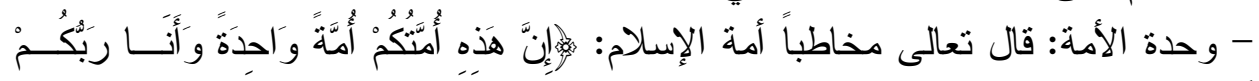

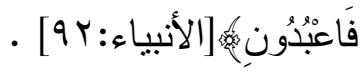

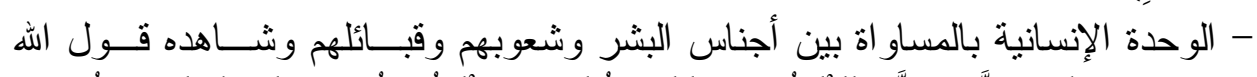

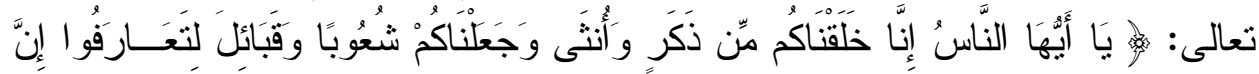




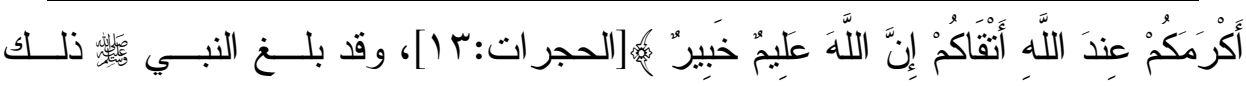

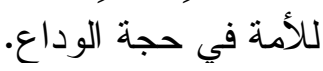

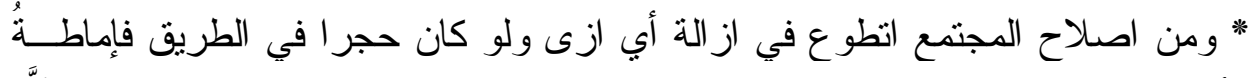

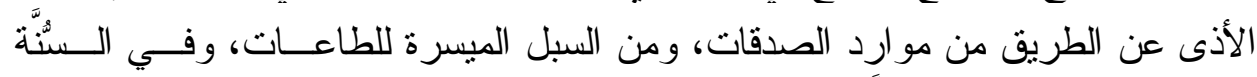

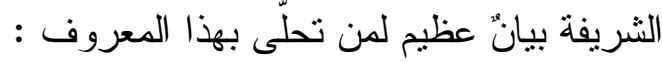

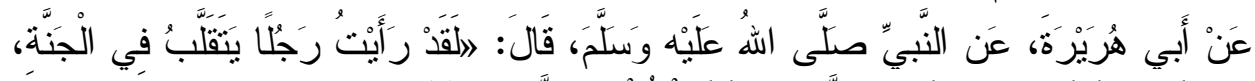

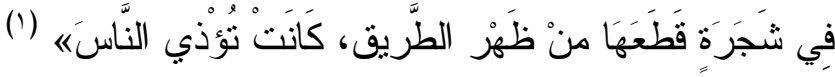

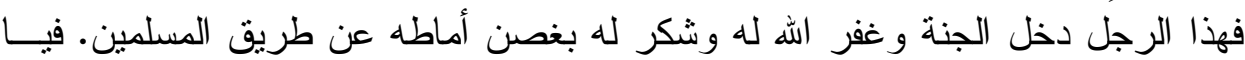

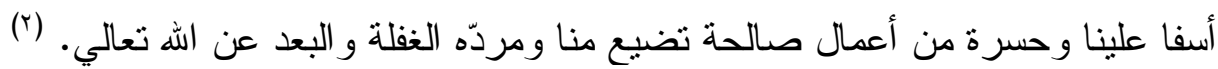

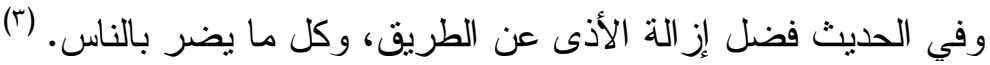

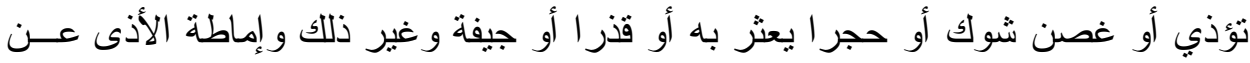

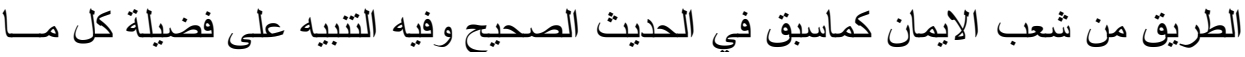

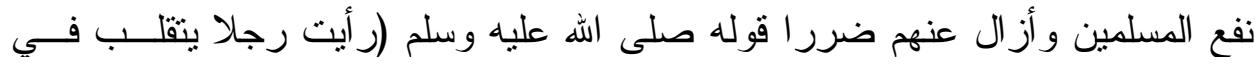

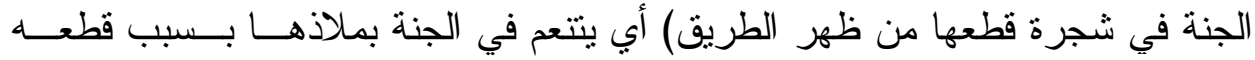

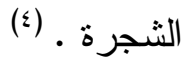

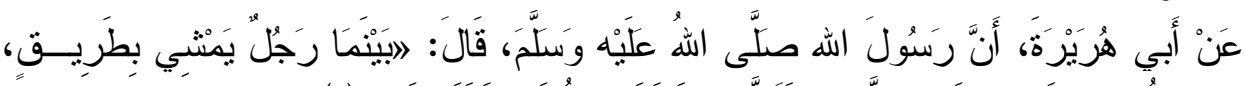

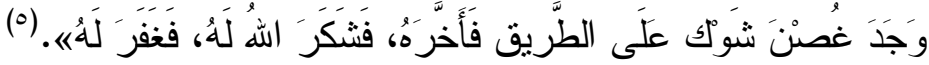

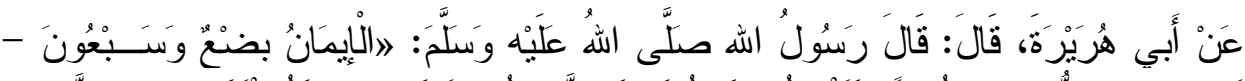

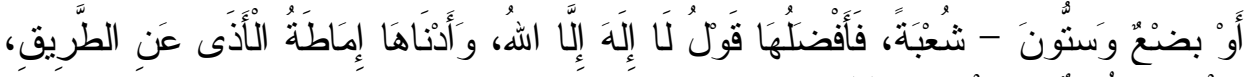

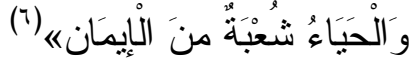

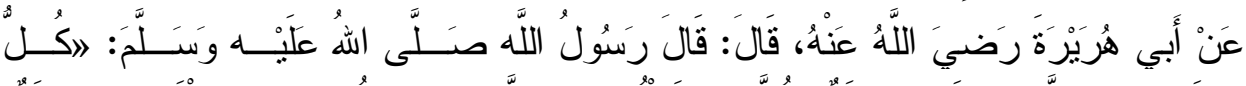

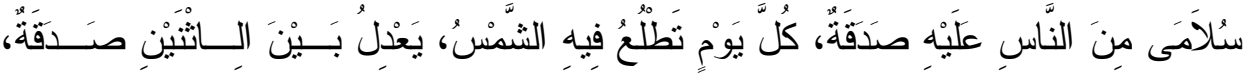

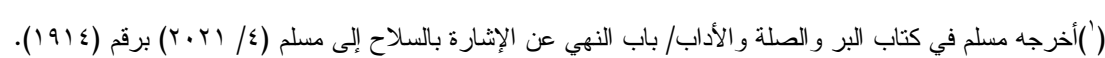

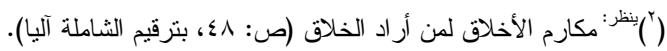

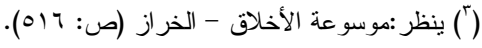

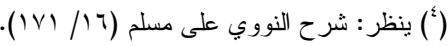

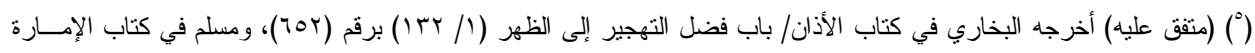

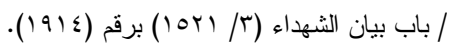

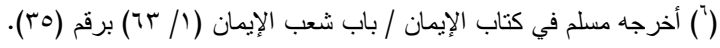




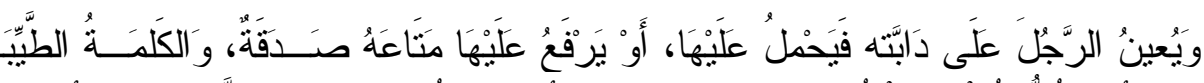

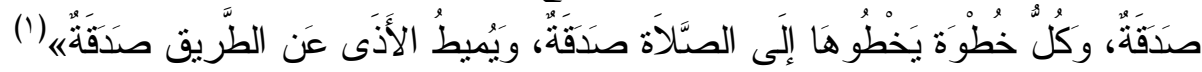

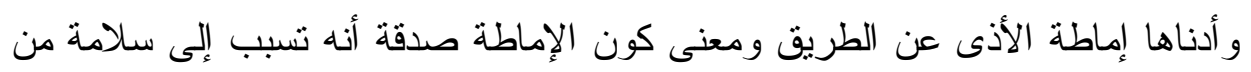

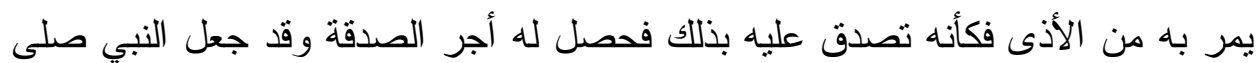

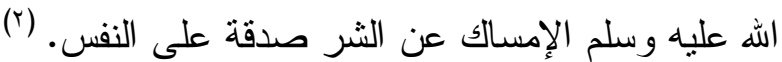

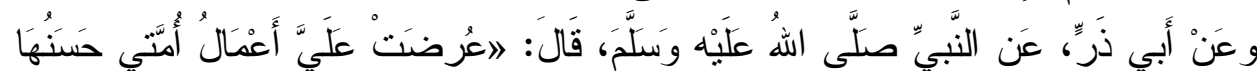

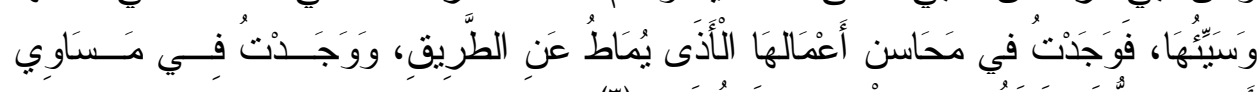

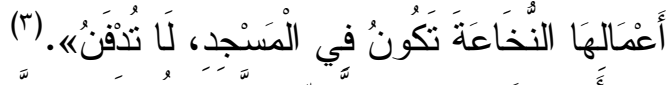

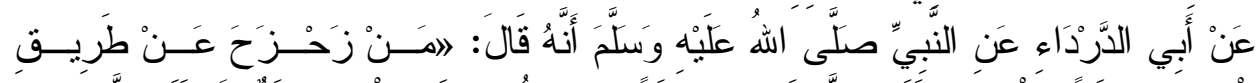

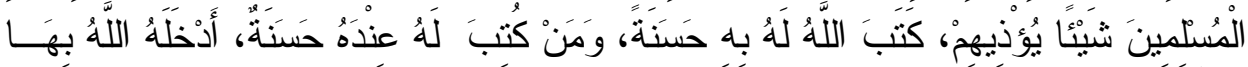

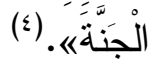

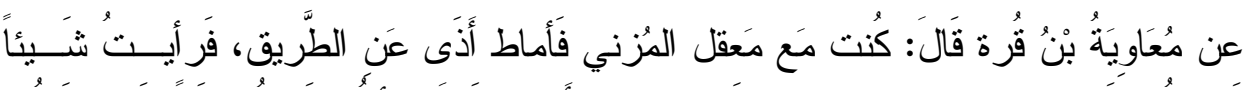

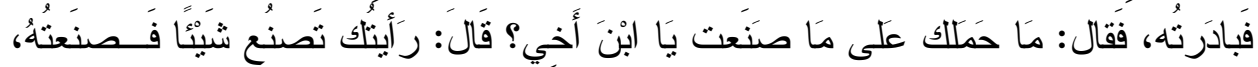

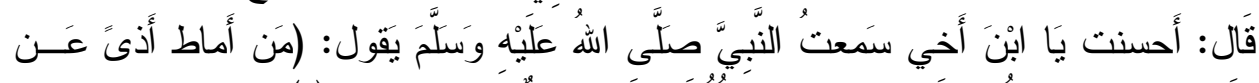

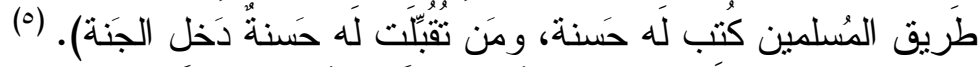

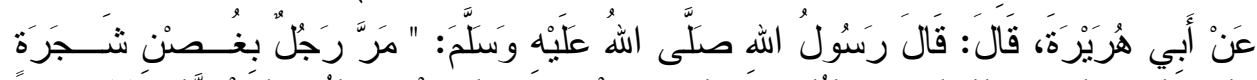

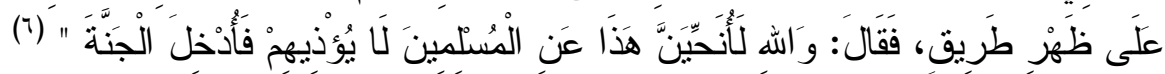

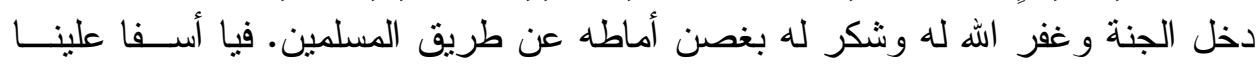

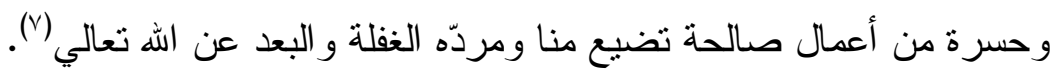

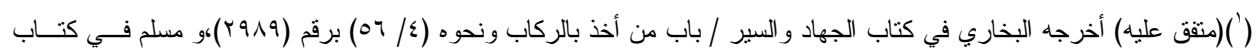

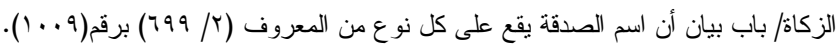

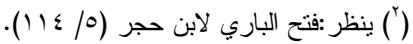

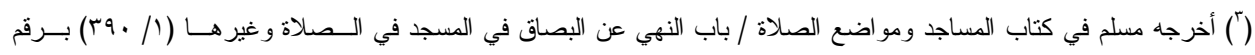

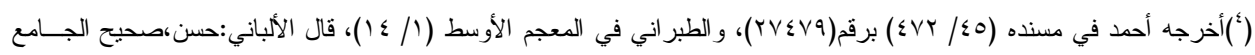

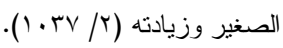

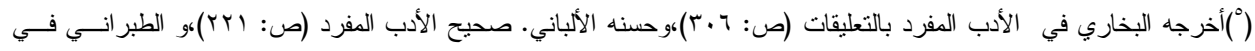

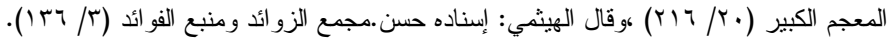

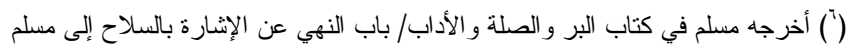


المطلب الثاني: أثرها في الإصلاح الأسري والاجتماعي.

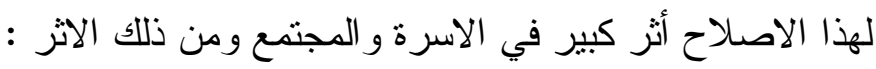

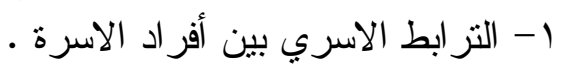

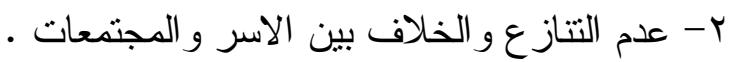

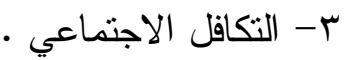

ع- وحدة الصف.

0- عدم وجود خصومات بين أفر اد الاسر و المجتمعات. 
المبحث الثاني: العمل الخيري وأثره في الإصلاح المــالي والاقتهـصادي مــن خــله الأحاديث النبوية. المطلب الأول: الأحاديث الواردة في الإصلاح المالي والإتصادي.

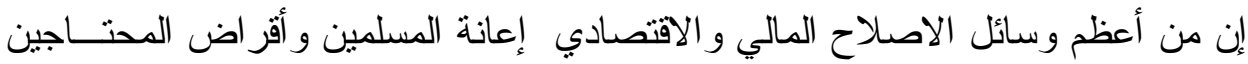

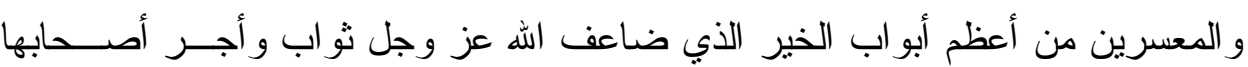

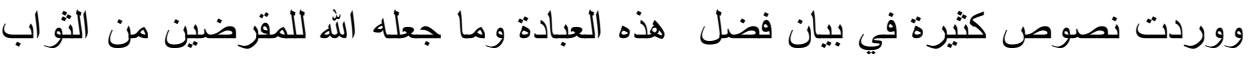

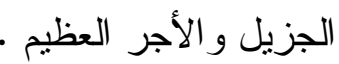

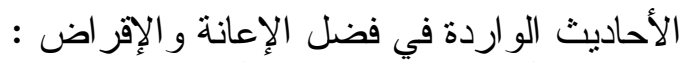

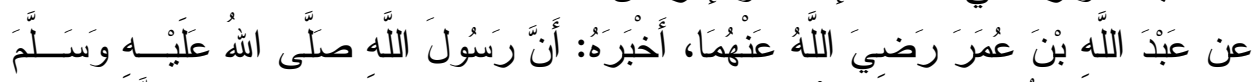

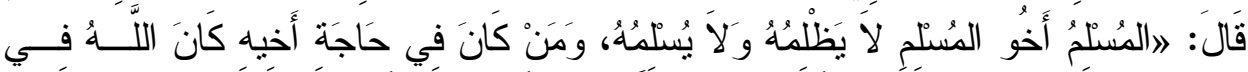

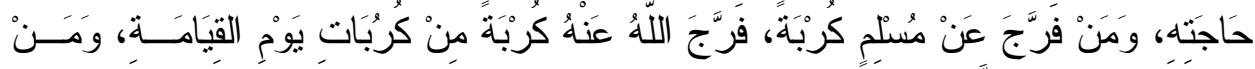

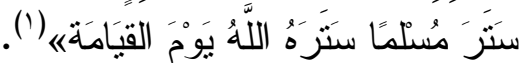

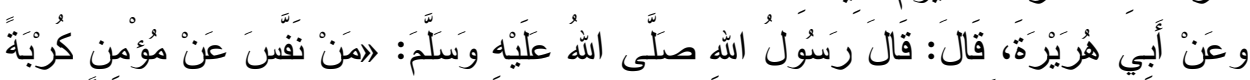

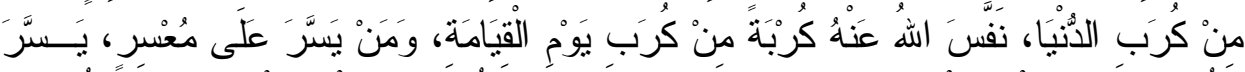

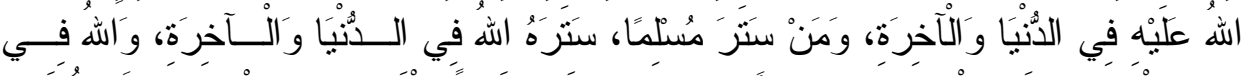

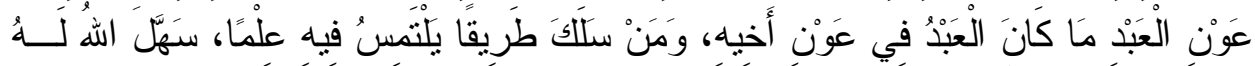

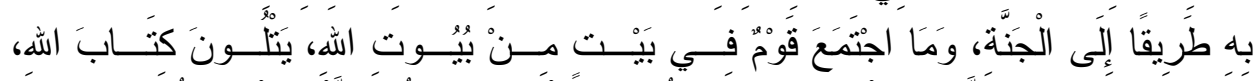

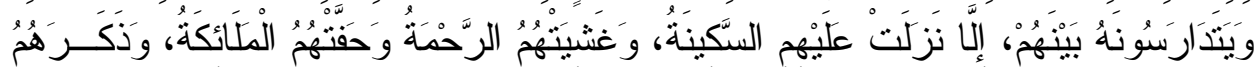

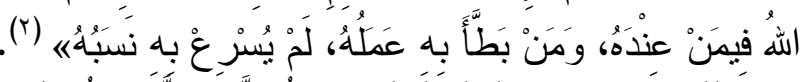

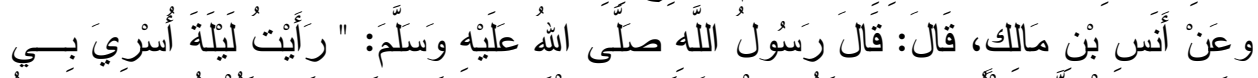

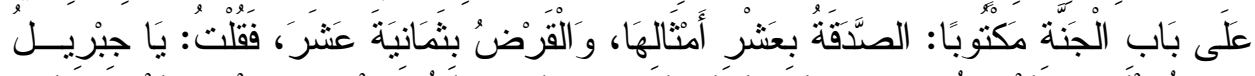

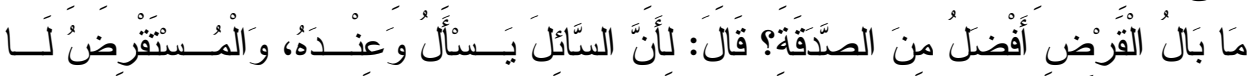

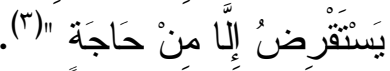

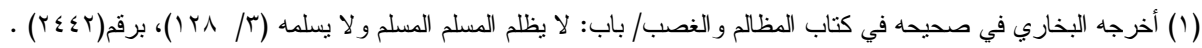

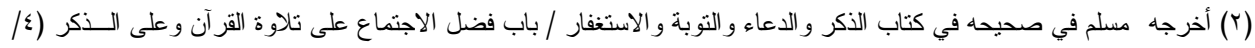

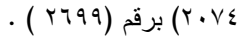

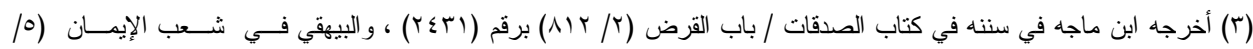

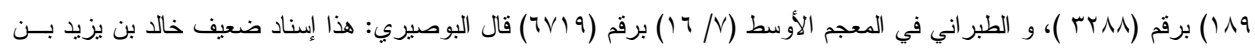

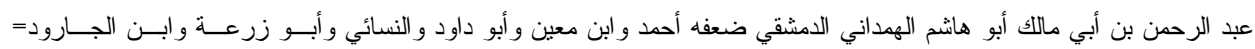




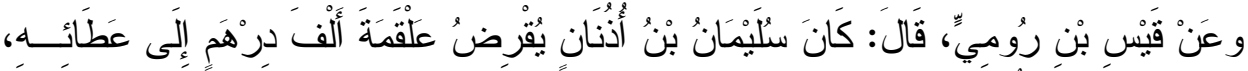

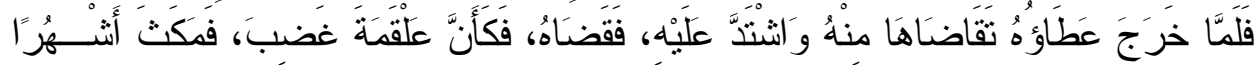

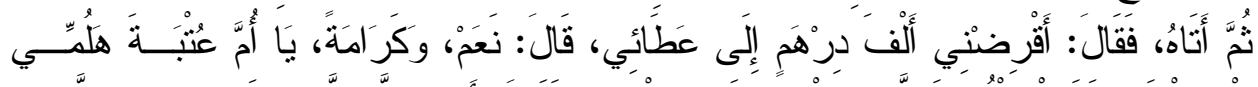

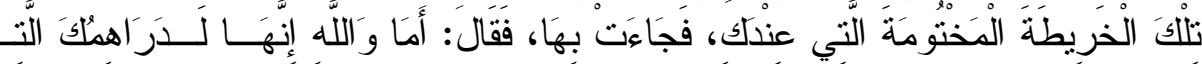

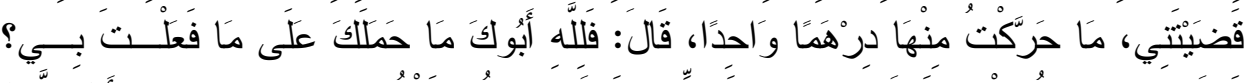

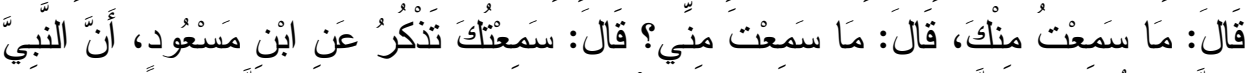

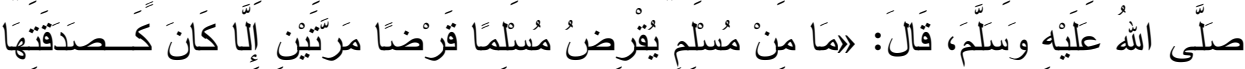

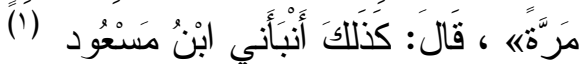

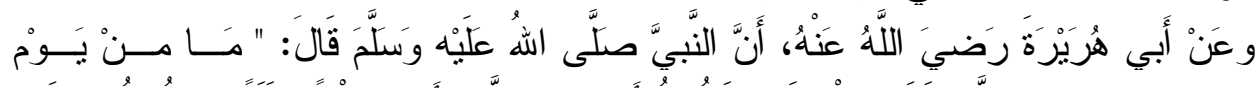

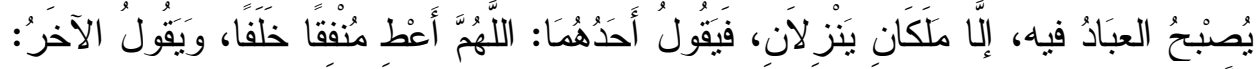

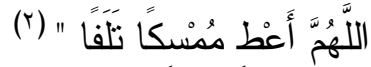

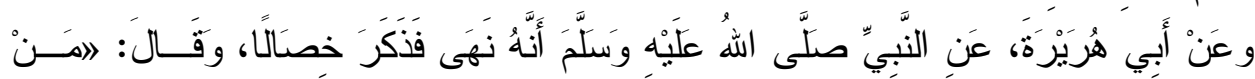

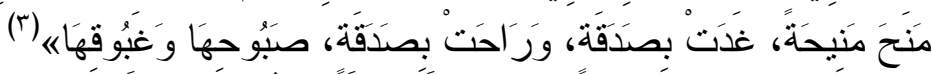

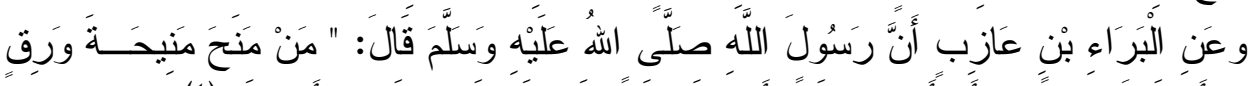

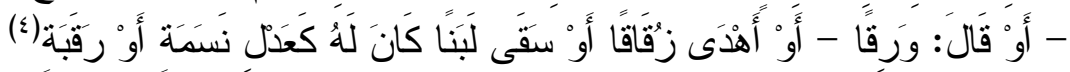

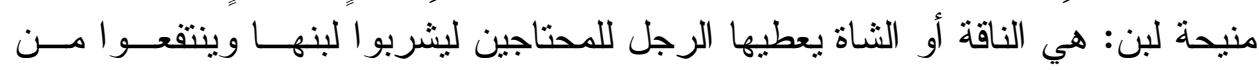

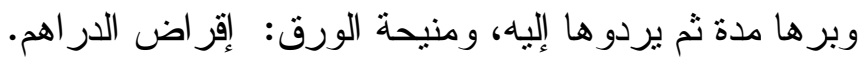

=و الساجي و العقيلي و الدارقطني وغير هم ووثقه أحمد بن صالح المعري وأبو زرعة الدمشقي وقال ابن حبان هو من فقهاء الشام كــان

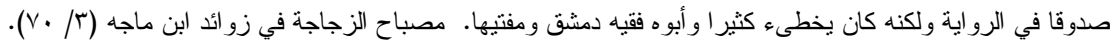

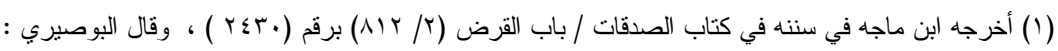

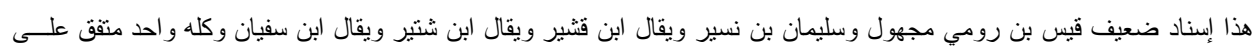

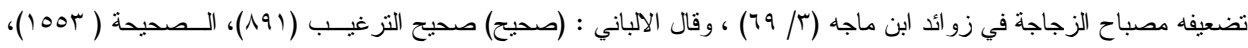

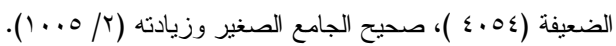

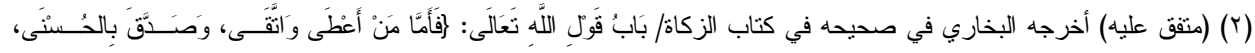

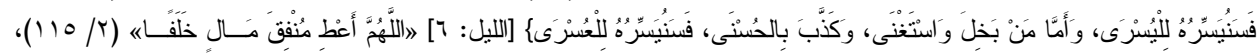

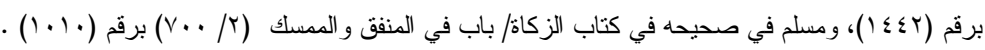

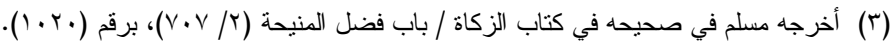

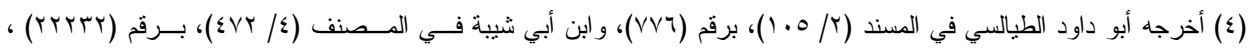

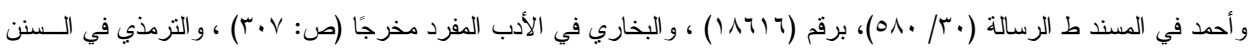

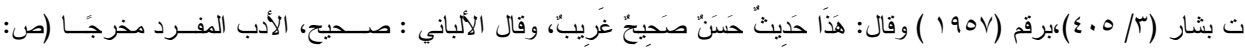




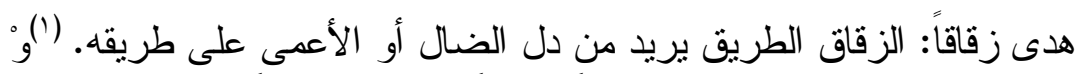

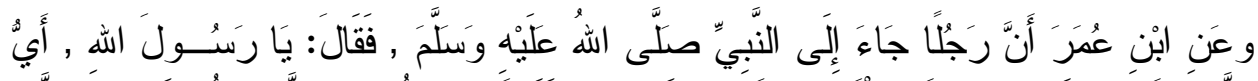

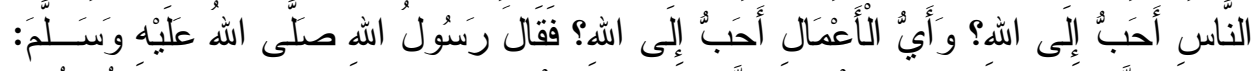

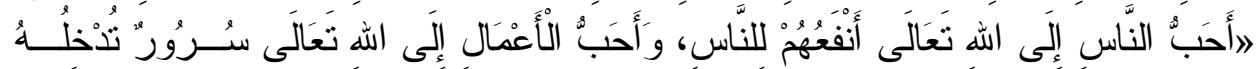

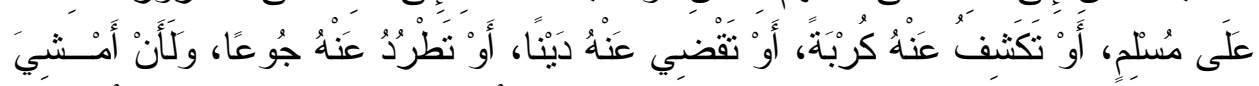

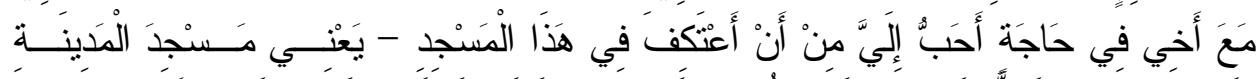

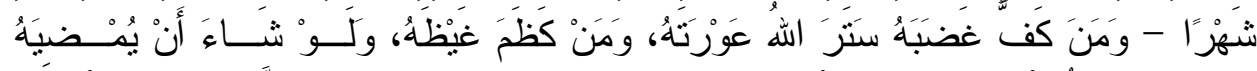

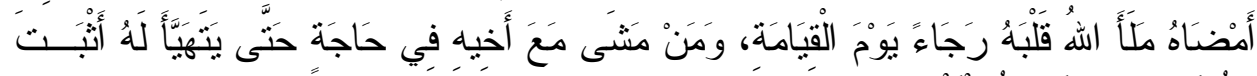

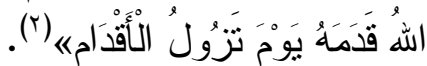

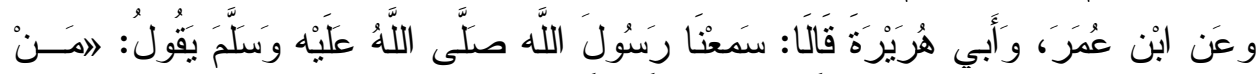

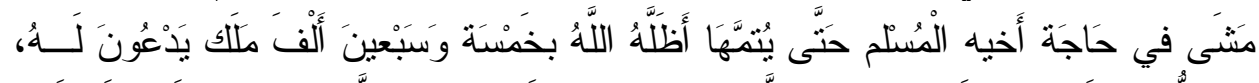

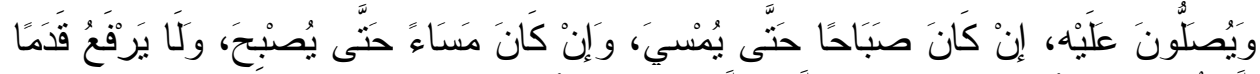

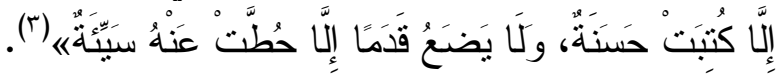

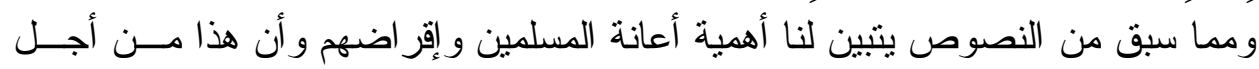

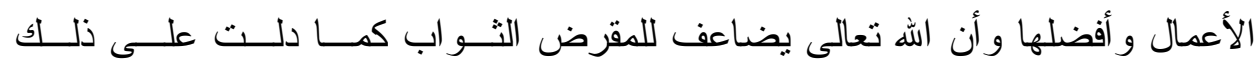
النصوص.

\section{ومن ذلك الصدقة على الفقراء و المحتاجين من الأهل والأقارب.}

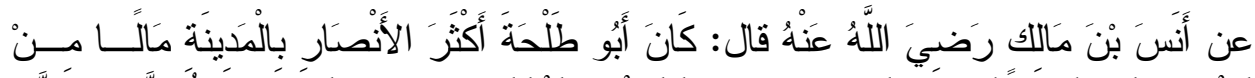

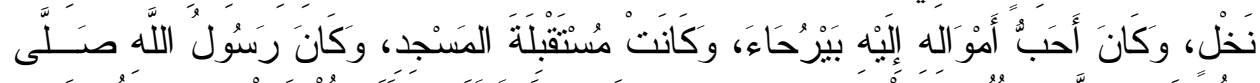

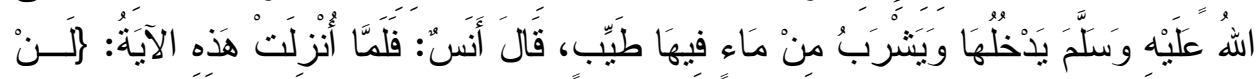

(1) انظر : فتح الباري شرح صحيح البخاري ، لأحمد بن علي بن حجر أبو الفضل العسقلاني الــشافعي، الناثــر : دار المعرفــة -

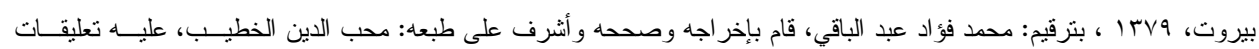

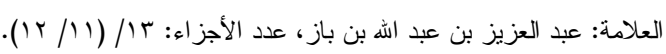

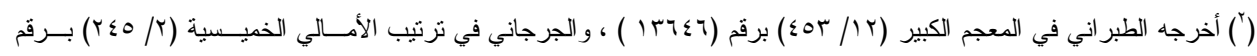

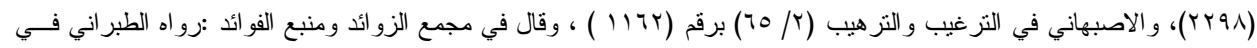

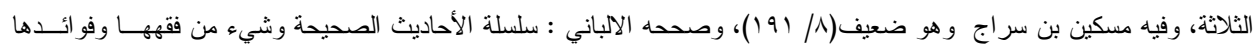

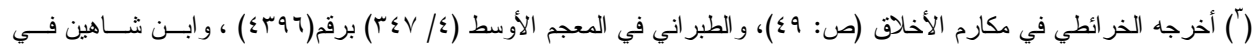

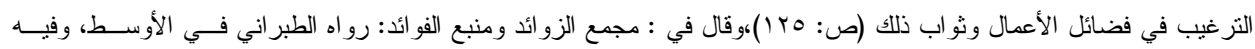

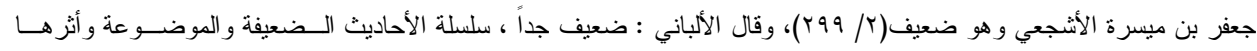

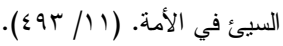




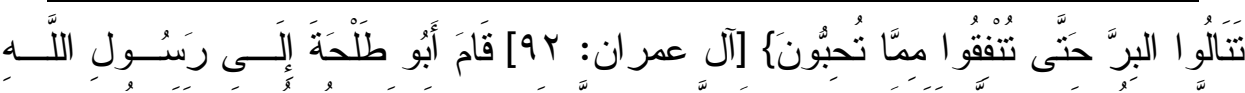

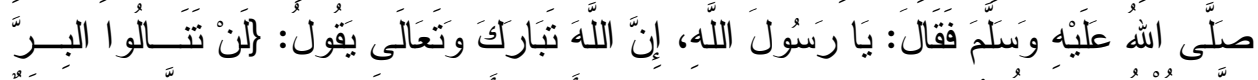

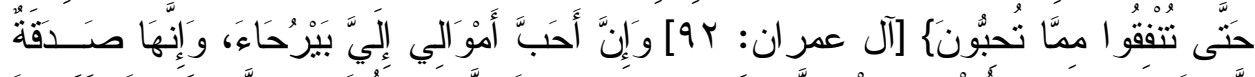

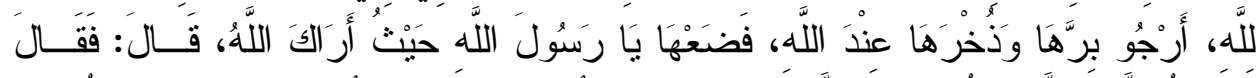

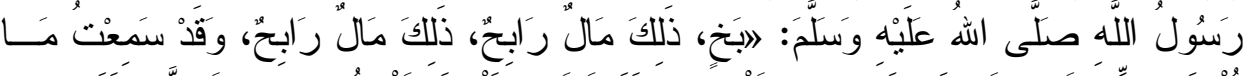

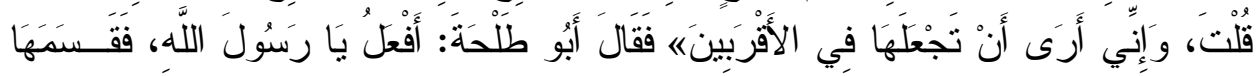

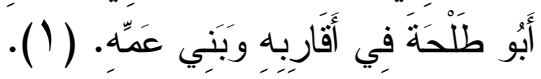

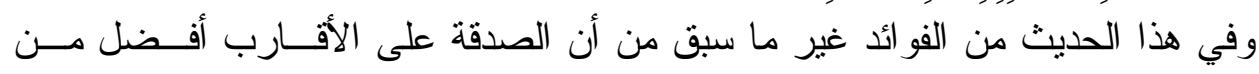

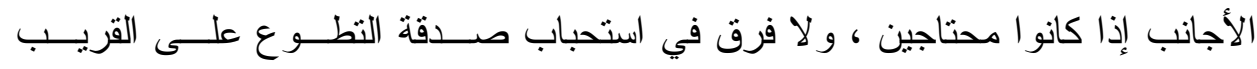

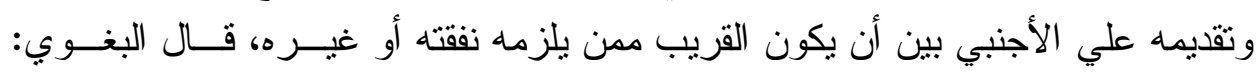

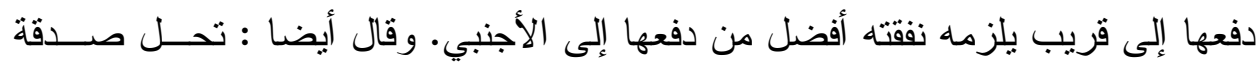

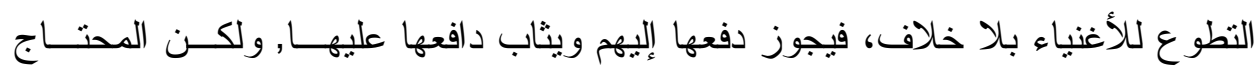

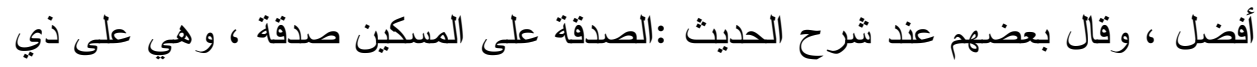

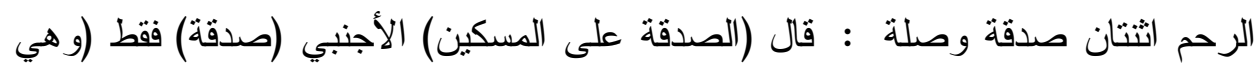

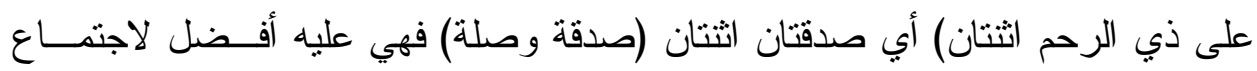

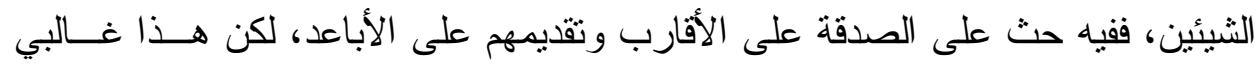

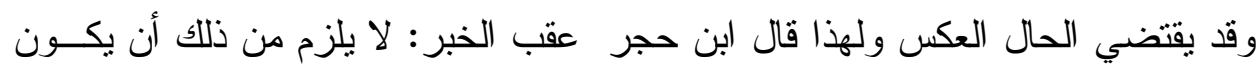

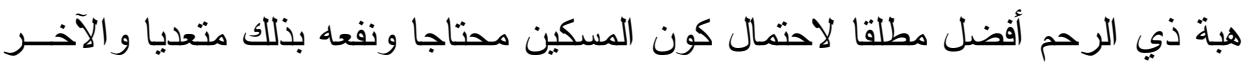
بعكسه.

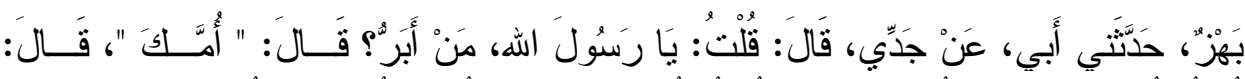

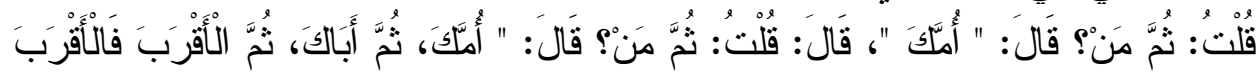

(r) ."

و النبي عليه صلى الله عليه وسلم يبين لأصحابه فقه الأولويات فمن غير المقبول لا مـن

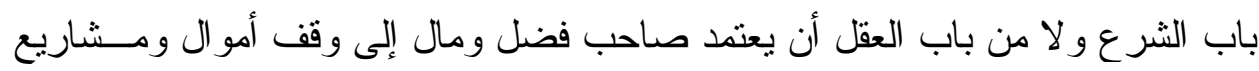
و أعمال بر مختلفة يريد بها الأجر من الله جل وعلاب وفي أقاربه من هو محتاج.

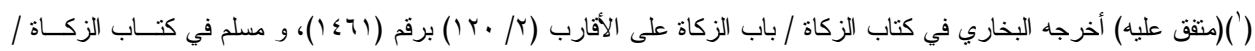

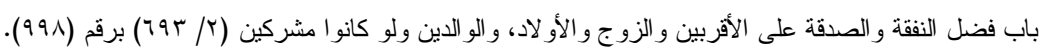

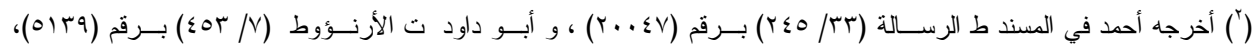

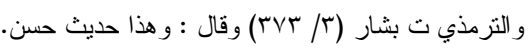




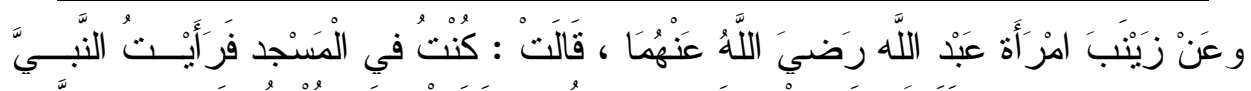

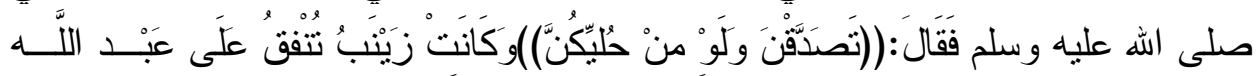

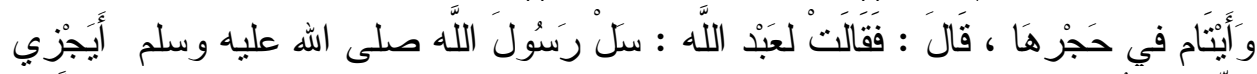

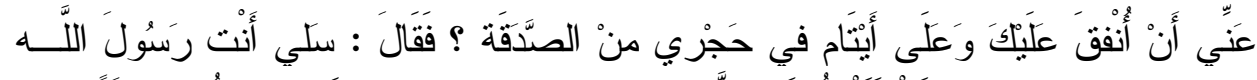

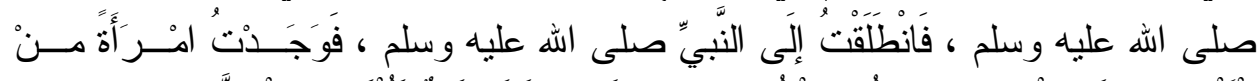

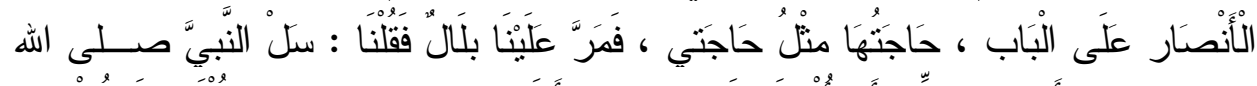

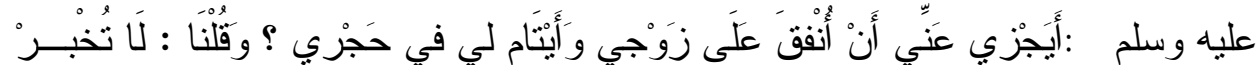

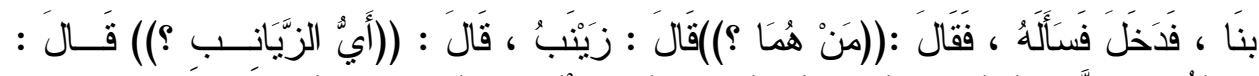

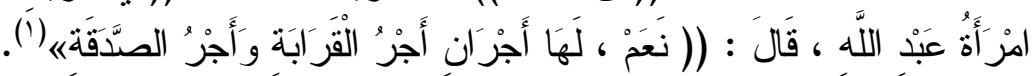

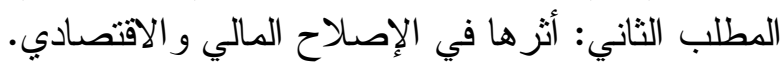
من آثار الاصلاح المالي و الاقتصادي: الإني 1- 1 سد حاجة الفقر اء.

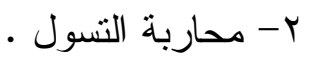
r- محاربة البطالة.

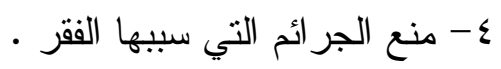
0- اعانة الفقير لقضاء حو ائجه. 
المبحث الثالث: العمل الخيري وأثره في الإصلاح النفـسي والتربــوي مسن خــله الأحاديث النبوية. المطلب الأول: الأحاديث الواردة في الإصلاح النفسي والتربوي.

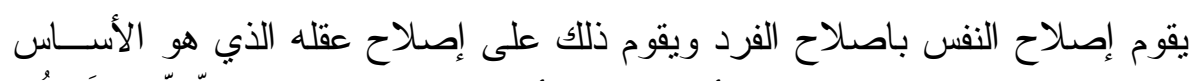

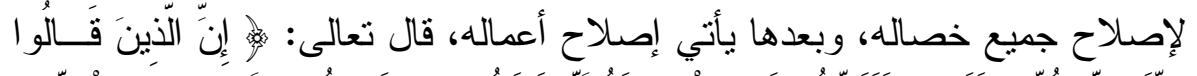

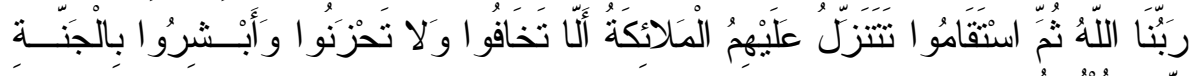

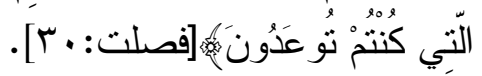

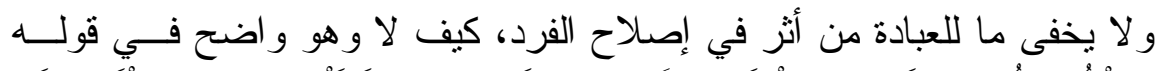

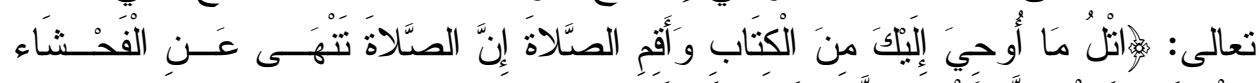

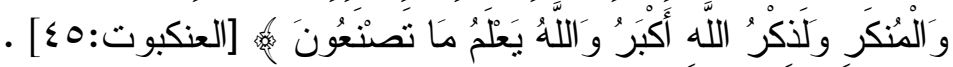

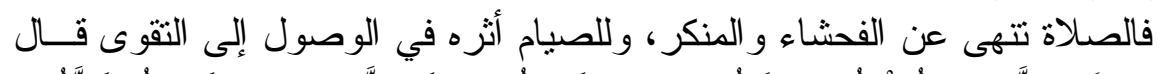

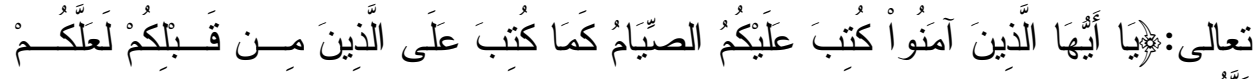

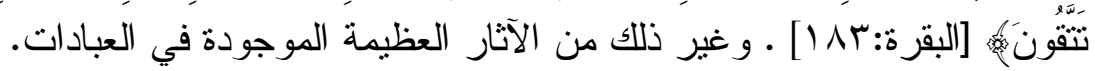

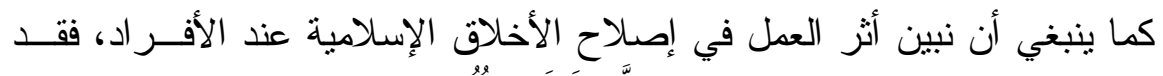

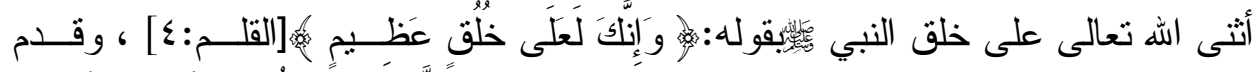

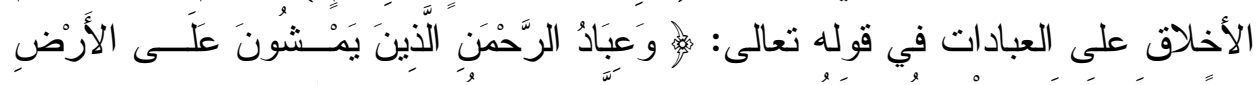

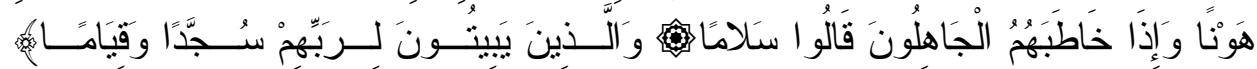

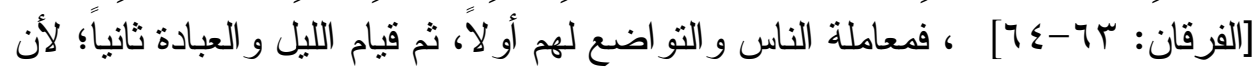

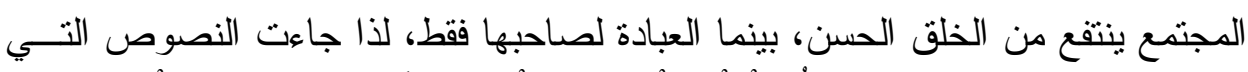

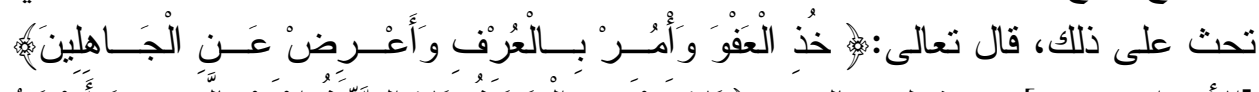

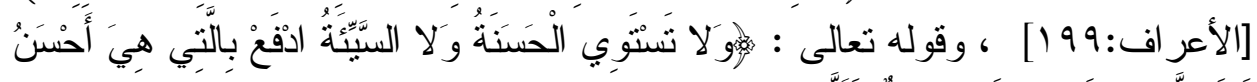

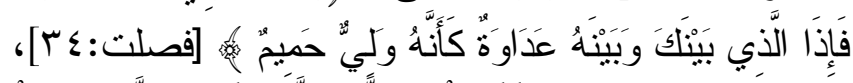

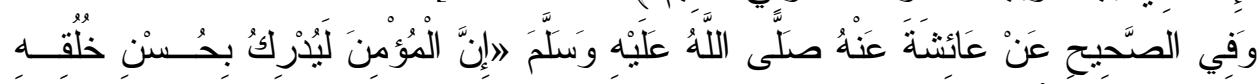

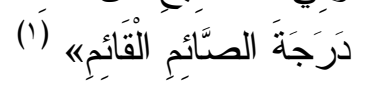

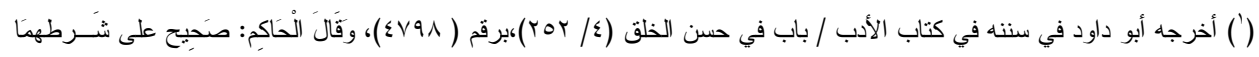

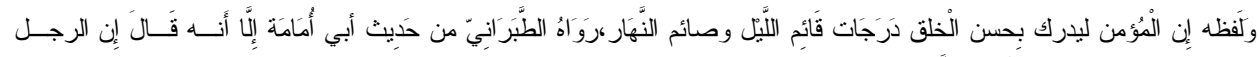

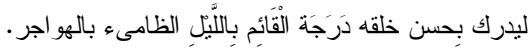




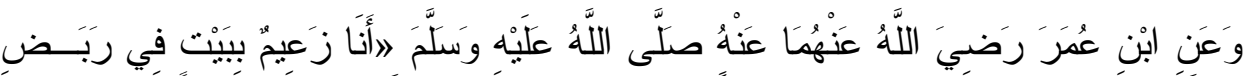

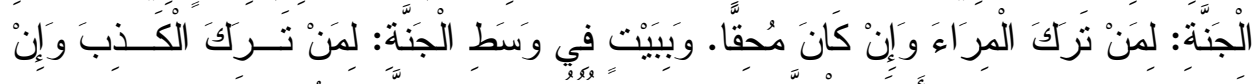

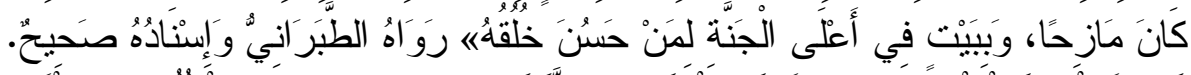

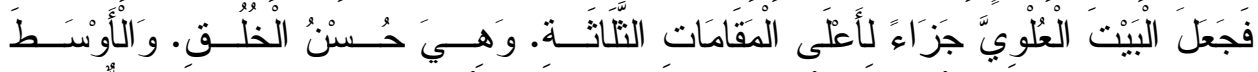

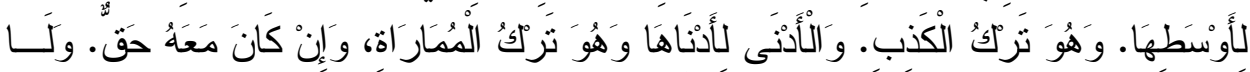

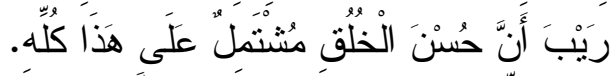

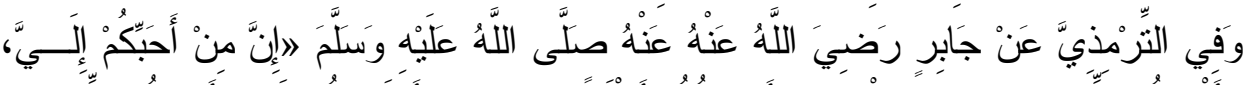

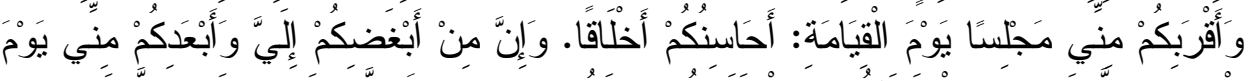

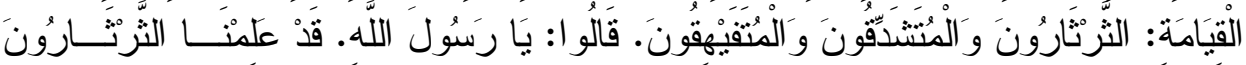

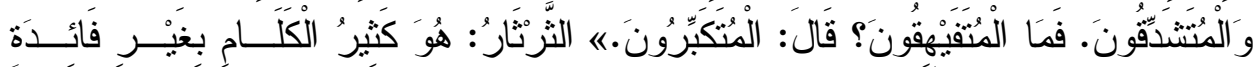

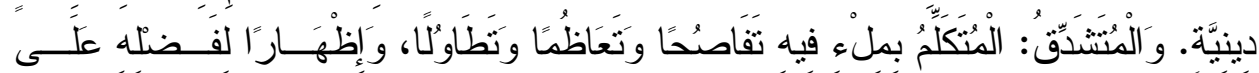

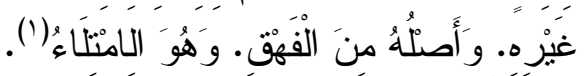

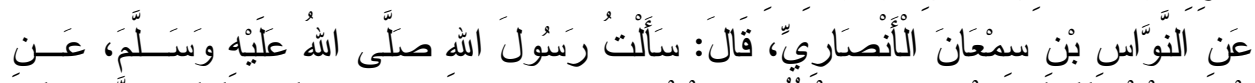

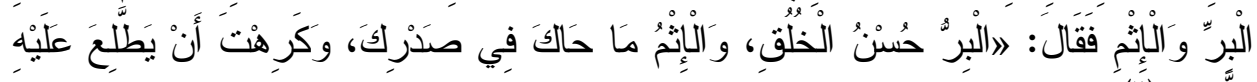
النَّاسُ" (ب)

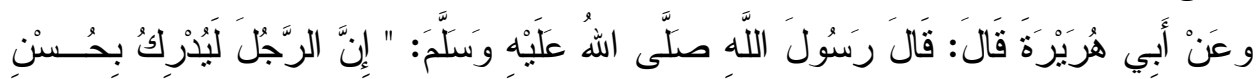

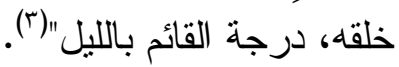

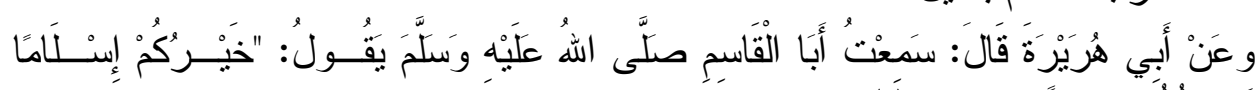

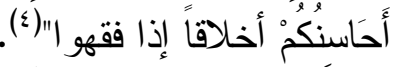

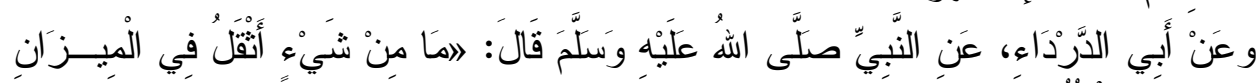

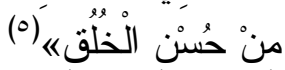

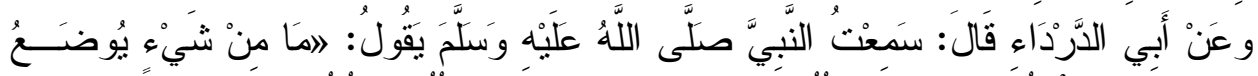

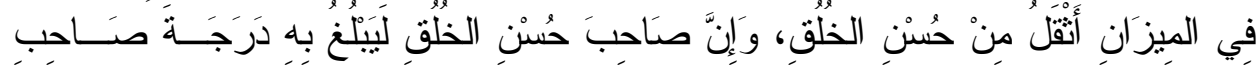

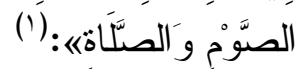

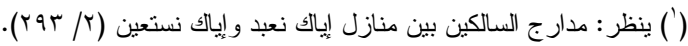

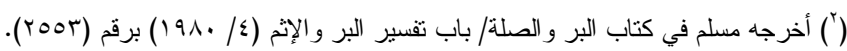

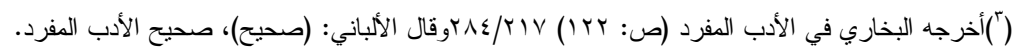

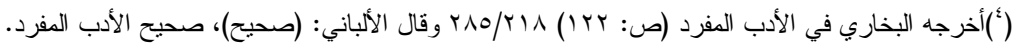

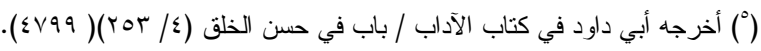




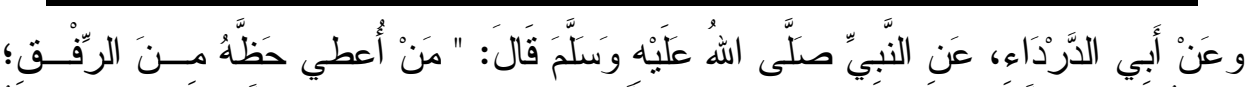

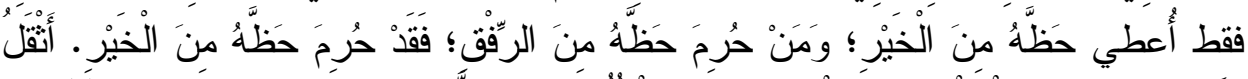

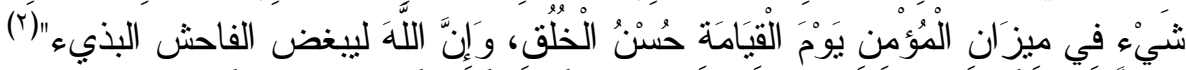

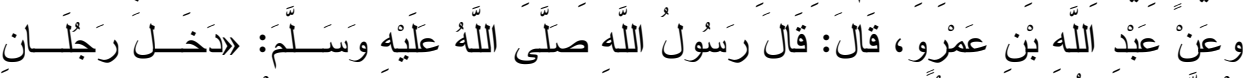

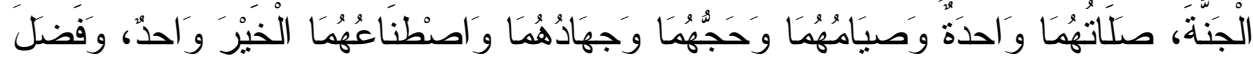

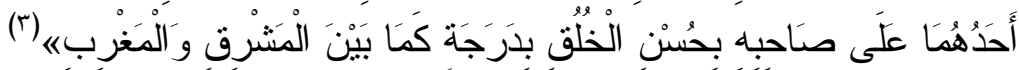

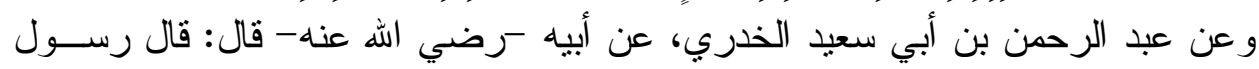
الله صلى الله عليه وسلم: (إن حسن الخلق وبر الو الدين وصلة الرحم يزدن في الأعمار ويعمرن الديار ويكثــرن

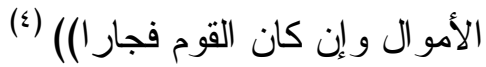

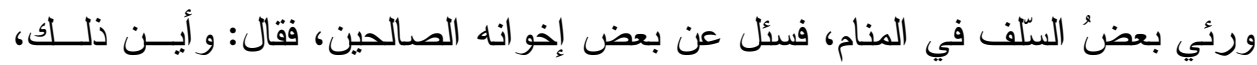
رُفع في الجنة بحسن خلقه. (•). ولقد صدق الثاعر لما قدر بقاء الأمم بيقاء الأخلاق فقال:

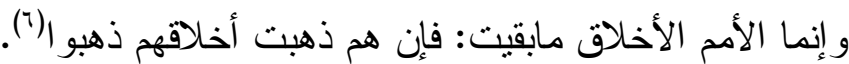

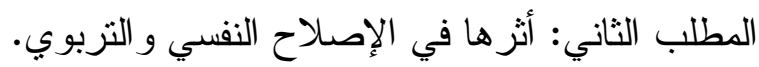

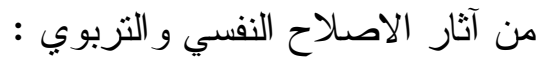

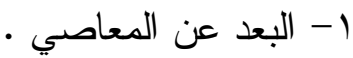
r- نرك المنكر ات و البدع. r- اصلاح النفس بالاخلاق الحسنة. ع - التربية الاسلامية الصحيحة.

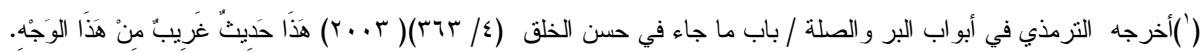

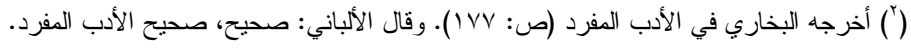

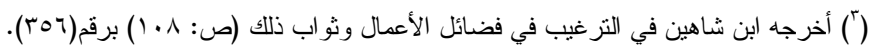

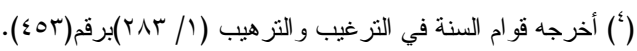

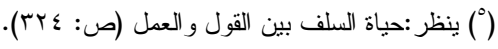

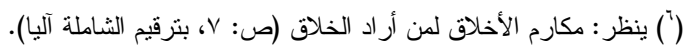


المبحث الرابع: العمل الخيري وأثره في الإصلاح الثقافي والفكري من خلا الأحاديث النبوية.

المطلب الأول: الأحاديث الواردة في الإصلاح الثقافي و الفكري

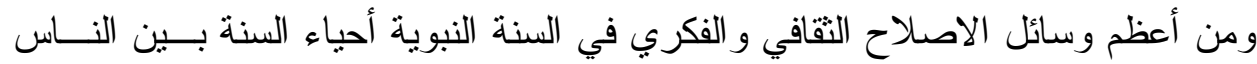

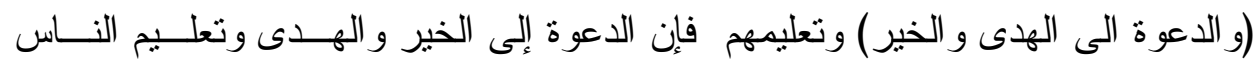

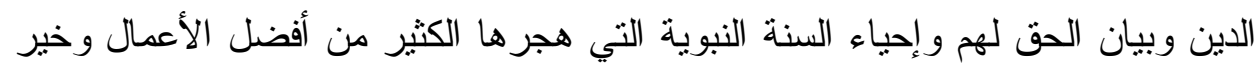

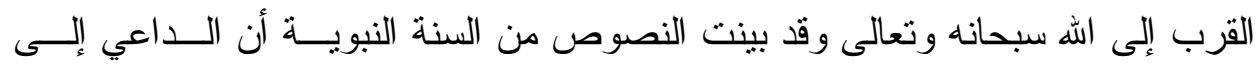

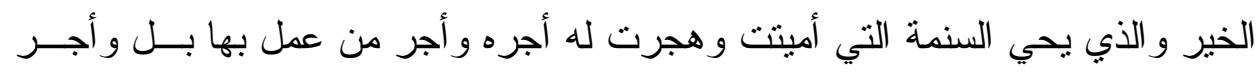

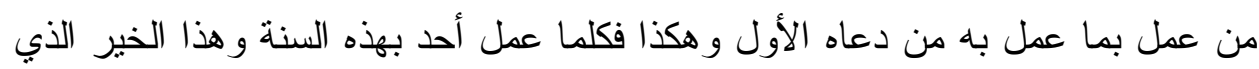

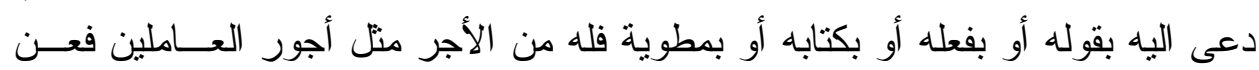

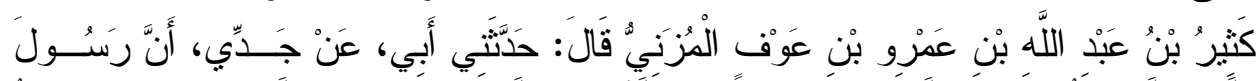

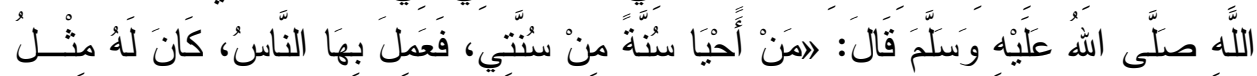

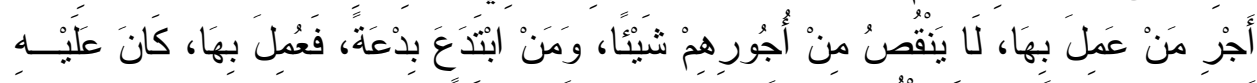

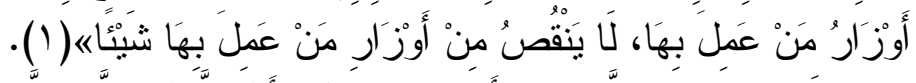

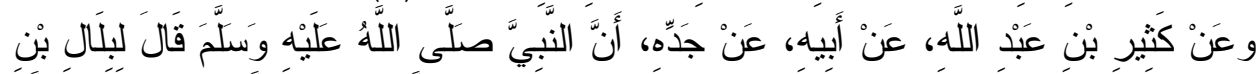

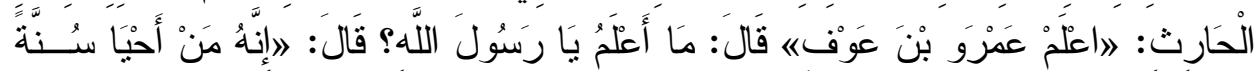

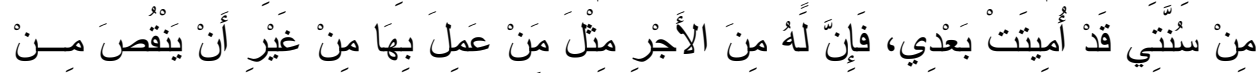

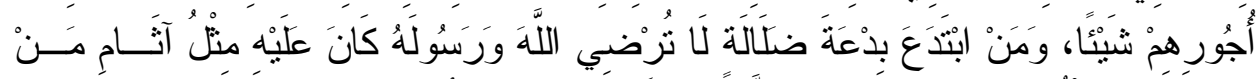

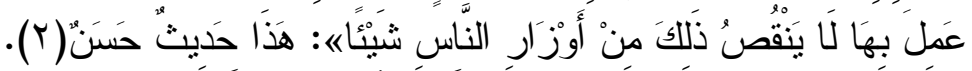

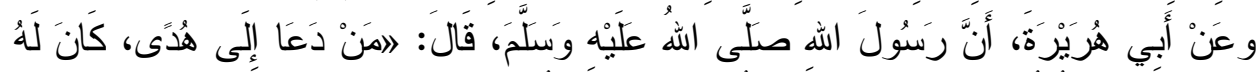

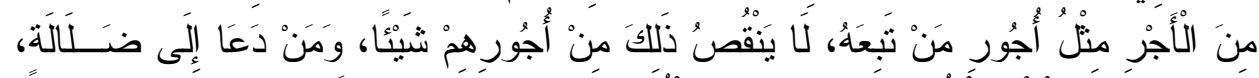

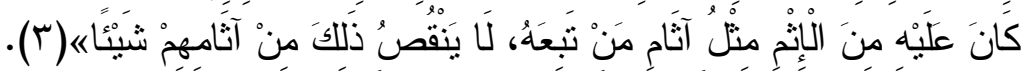

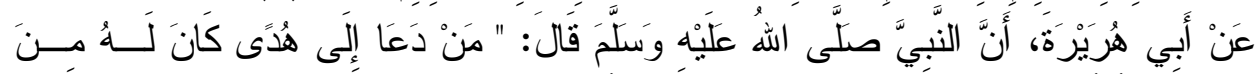

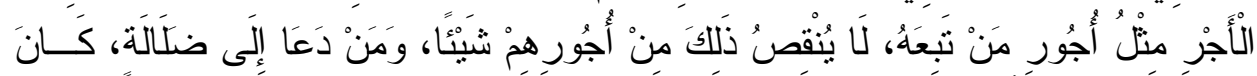

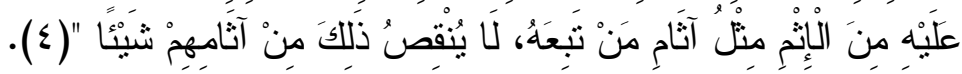

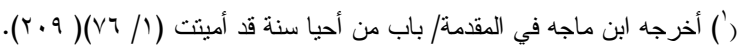

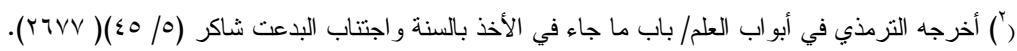

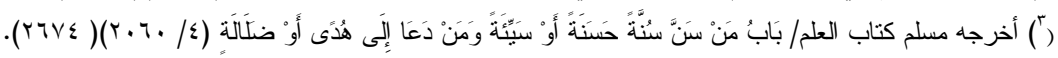

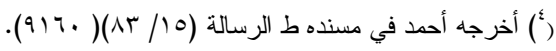


هذه الأحاديث صريحة في الحث على استحباب سن الأمور الحسنة وتحريم سن الأمور

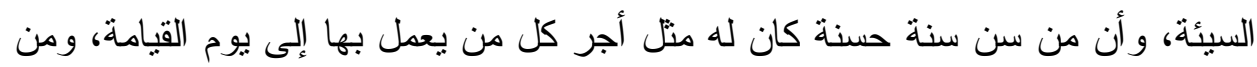

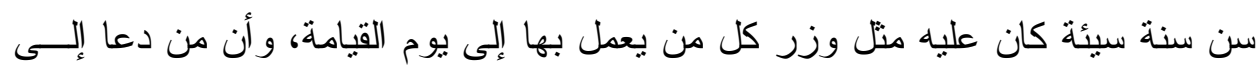

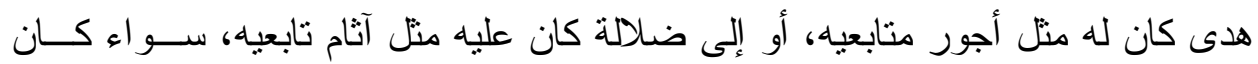

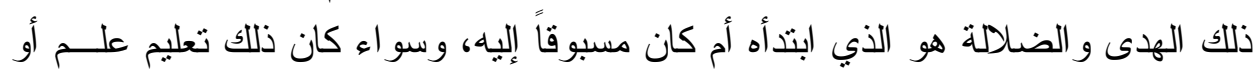

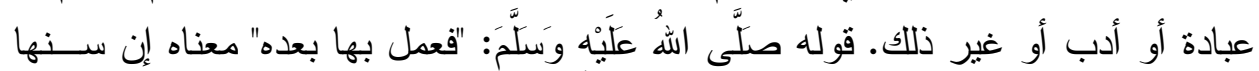
سواء كان العمل في حياته أو بعد موته( (1).. المطلب الثاني: أثرها في الإصلاح الثقافي و الفكري. من آثار الاصلاح الثقافي و الفكري: 1- انتشار العلم و الحق. r- بلة الجهل . r- محاربة الانحر افات و التطرف الفكري. ع- انتشار النقافة الوسطية بين الناس. ثالثا: الخاتمة وما تحتويه من نتائج وتوصيات. وفهارس وهي كما يأتي: 


\section{الخاتمة}

الحمد لله الذي تتم به الصالحات حمداً كما ينبغي لجلال وجهه و عظيم سلطانه، و الصلاة

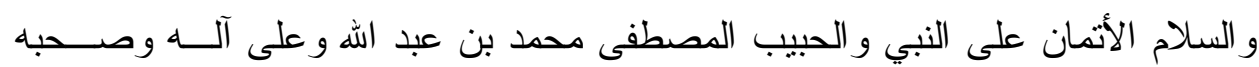
ومن تبعهم ليوم الدين.

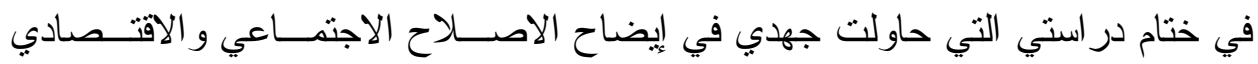

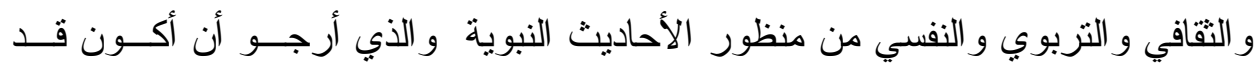

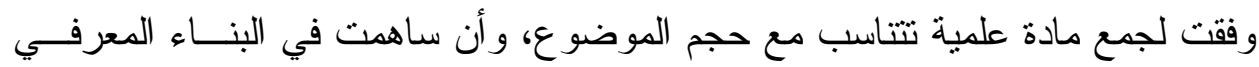
لموضوع العمل الاجتماعي في السنة النبوية.

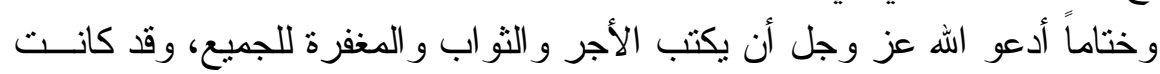

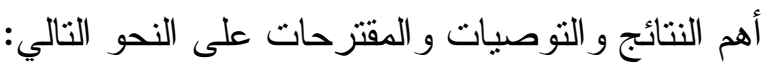

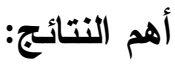
من خلال هذه الدر اسة توصل الباحث لهذه النتائج:

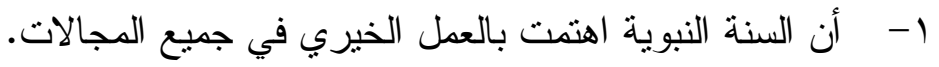

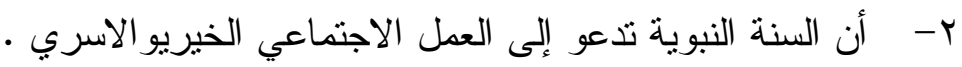

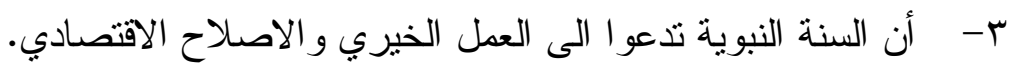

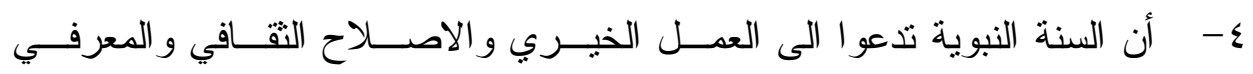
و الفكري.

0- أن السنة النبوية تدعوا الى العمل الخيري و الاصلاح النفسي و التربوي.

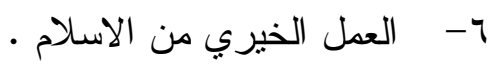




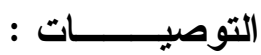

1- دعوة العلماء، و الفقهاء، و المتخصصين في البحث العلمي الاجتماعي و الثرعي

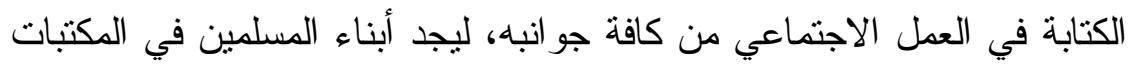

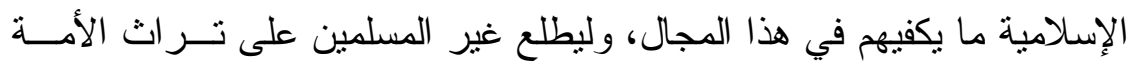

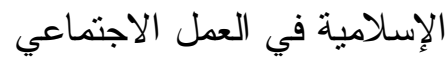

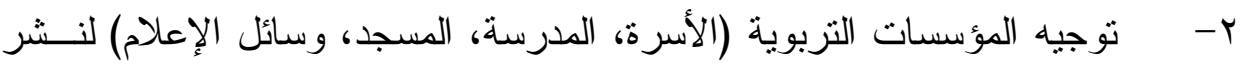
ثقافة وممارسة العمل الاجتماعي الخيري.

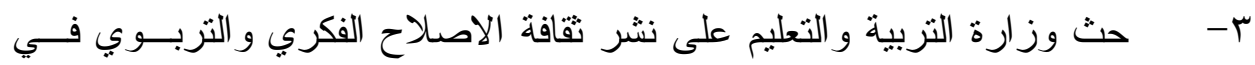
المدارس و الجامعات. ع - دعم وز ارة التزبة و التعليم مر اكز الخدمات الاجتماعية للأعمال التطوعية مادياً ومعنوياً وجعله في إدارة تربية وتعليم.

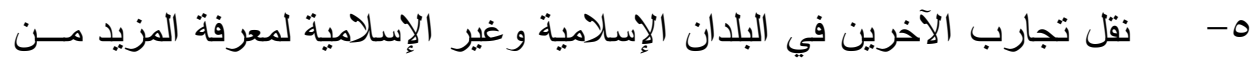

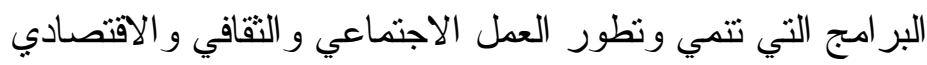
ثالثاً : المقترحات:

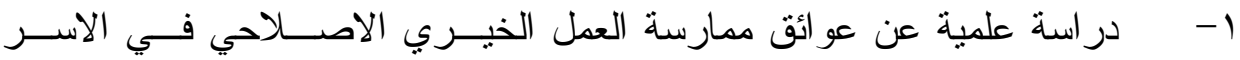
و المجتمع.

r- در اسة علمية عن عو ائق ممارسة العمل الخيري الاصلاحي الثقافي و الفكري.

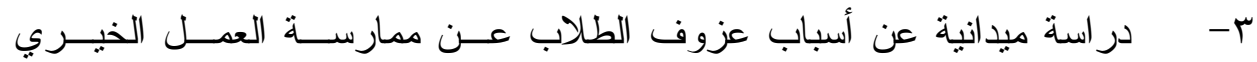
الاصلاحي. 


\section{فهرس المصادر و المراجع ·}

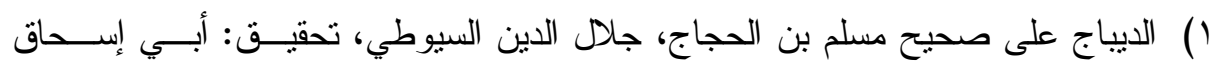

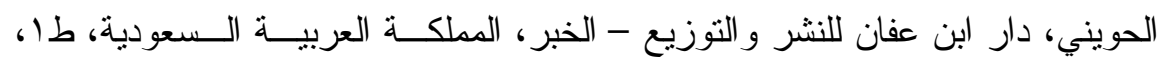

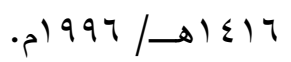

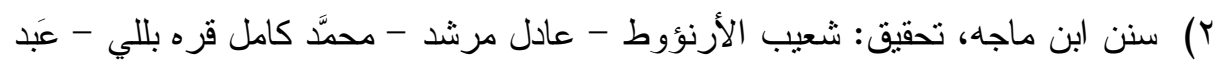

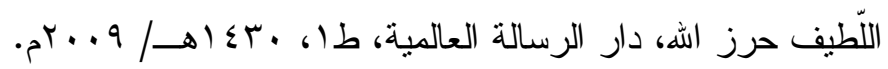

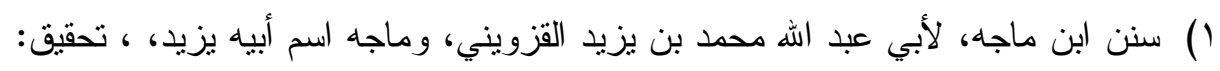
محمد فؤاد عبد الباقي، الناشر : دار إحياء الكتب العربية - فيصل عيسى البابي الحلبي.

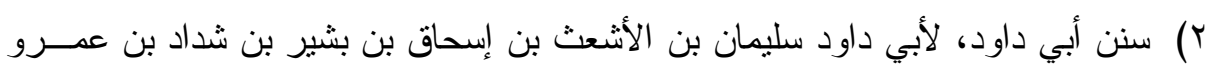

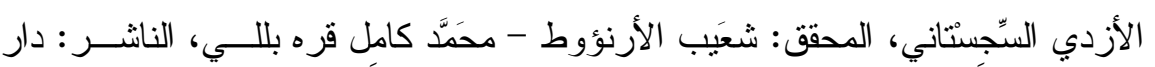

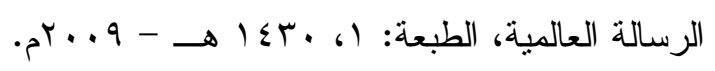

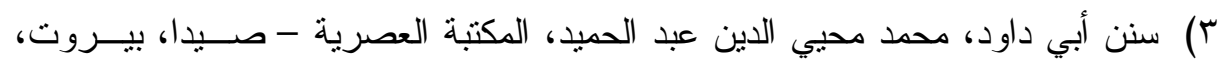

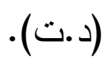

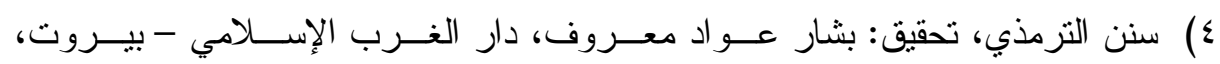

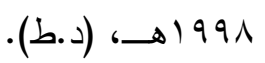

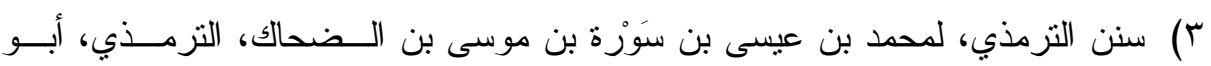

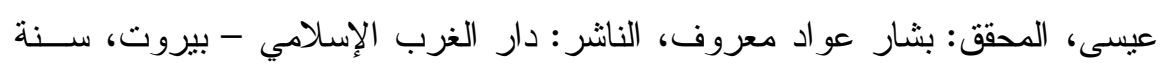

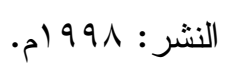

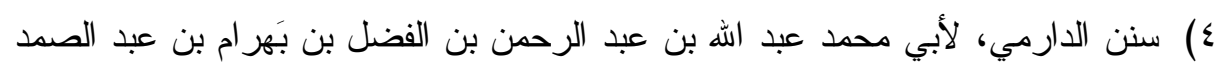

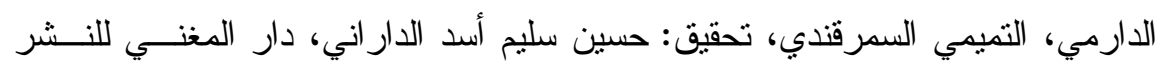

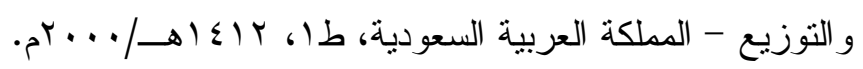

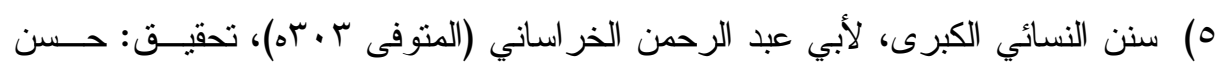

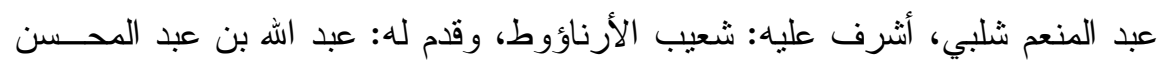

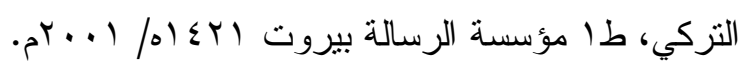

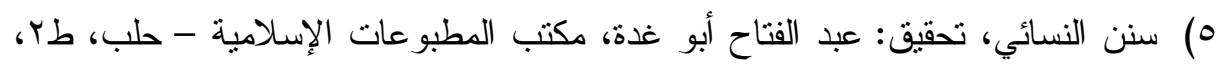

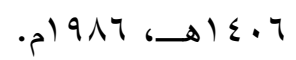

7) سير السلف الصالحين، قو ام السنة الأصبهاني، كرم بن حلمي بن فرحات بن أحمد، دار الر اية للنشر و التوزيع - الرياض. 
T) شرح الطيبي على مشكاة المصابيح، شرف الدين الطيبي، تحقيق: عبد الحميد هنداوي،

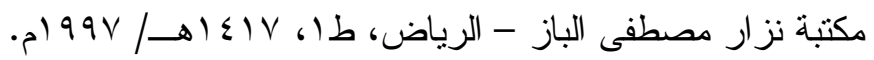

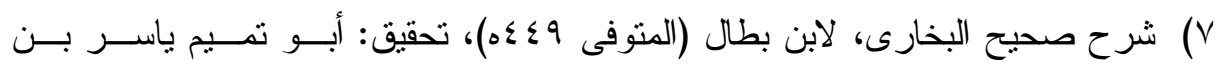

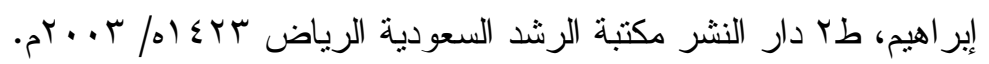

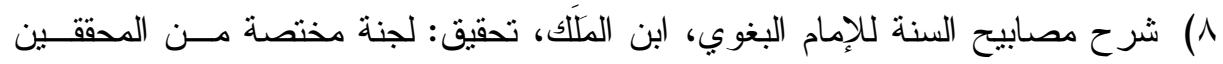

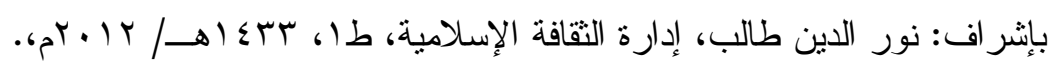

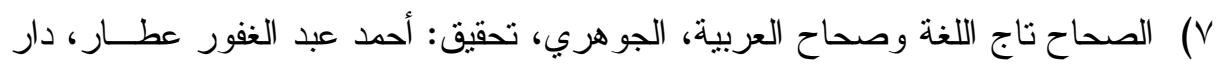

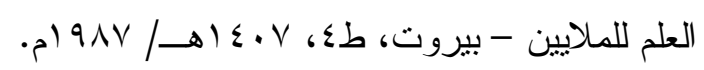

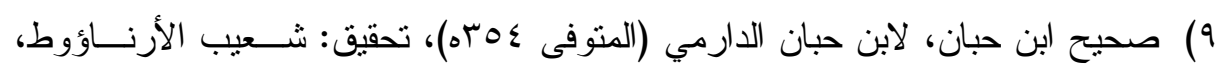

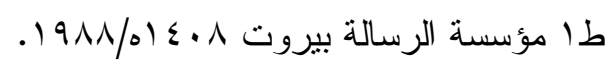

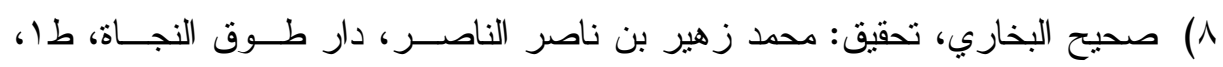
.

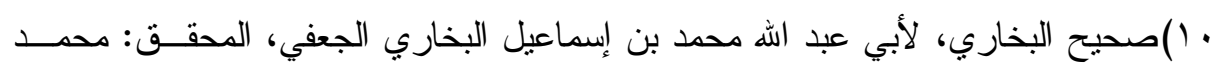

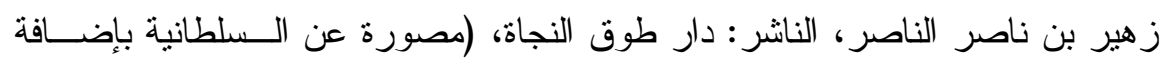

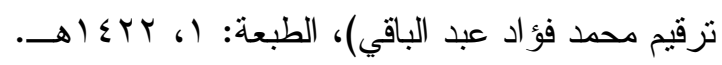

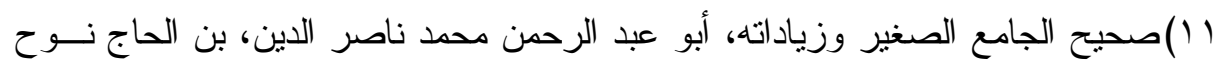

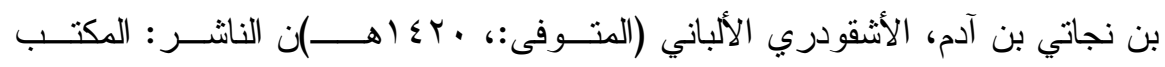
الإسلامي.

9) صحيح الجامع الصغير وزياداته، الألباني، المكتب الإسلامي، (د. ت).

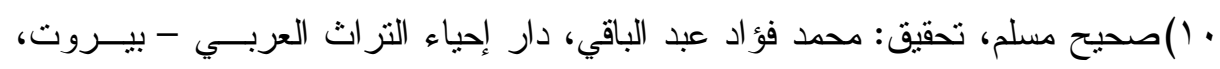
(ت)

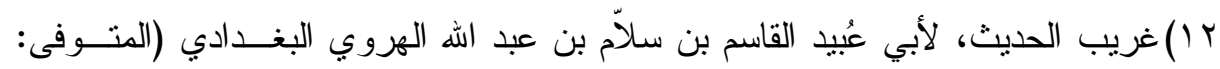

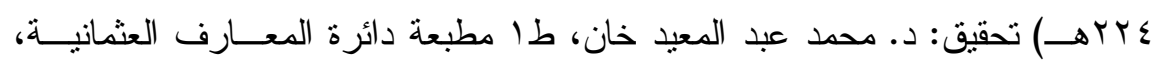

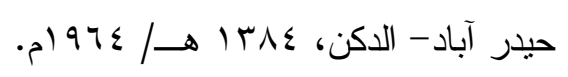

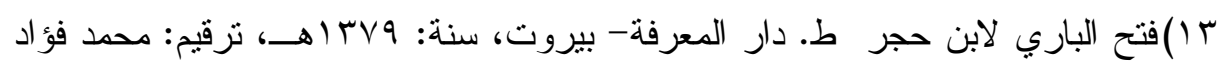
عبد الباقي، إثر اف: محب الدارين الدجري

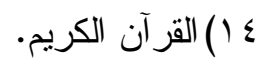

(1)كثف المشكل من حديث الصحيحين، ابن الجوزي، تحقيق: علي حسين البــواب، دار الوطن - الرياض، المملكة العربية السعودية، (د.ت). 


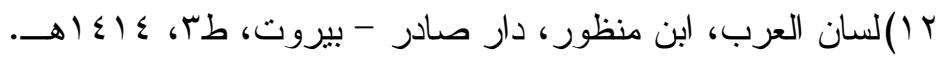

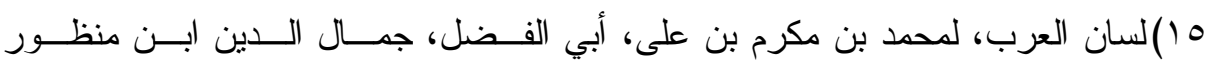

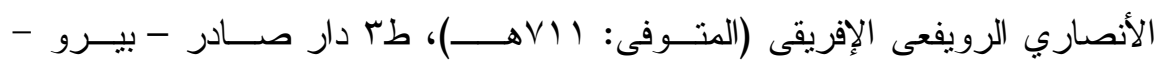
ـا

7 (1)مجمع الزو ائد ومنبع الفوائد، أبو الحسن الهيثمي، تحقيق: حسام الدين القدسي، مكتبـــة

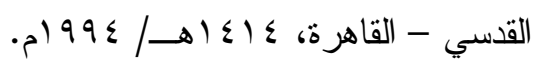

r (1)مجموع الفتاوى، تقي الدين أبو العباس أحمد بن عبد الحليم بن تيمية الحراني، تحقيـقن:

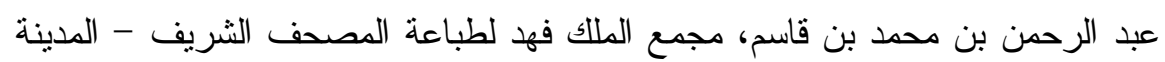

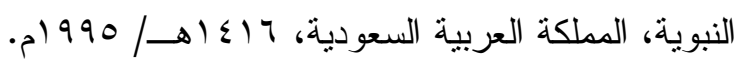

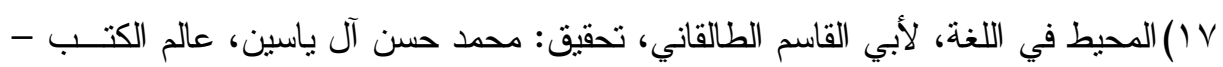

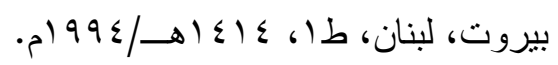

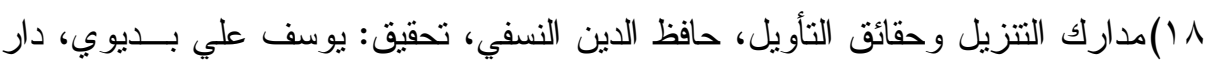

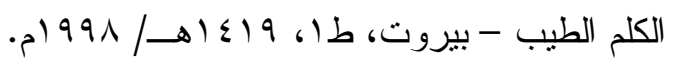

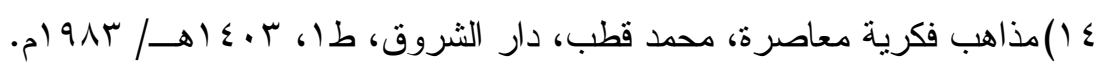

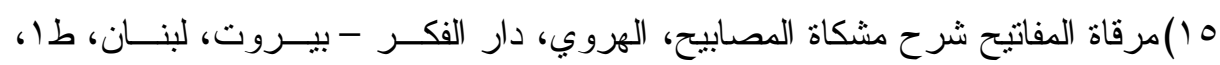

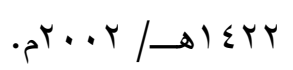

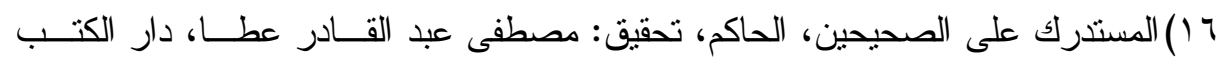

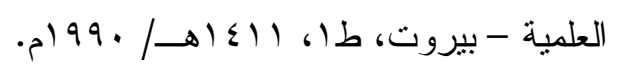

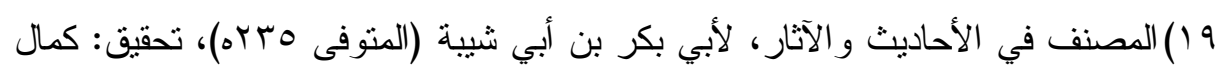

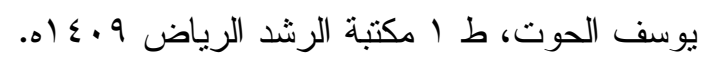

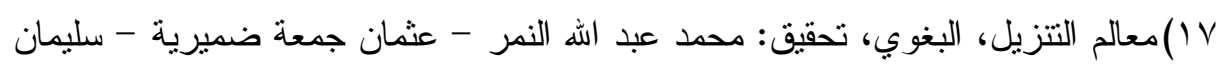

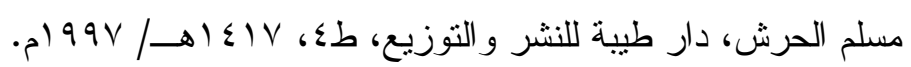

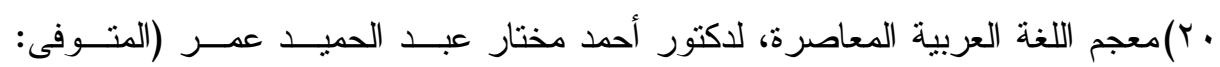

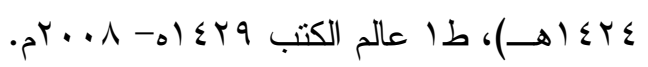

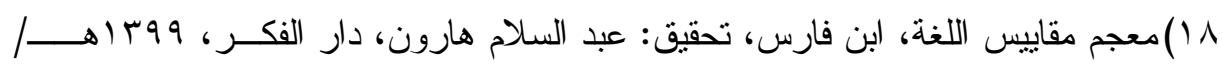

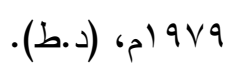

